\title{
Advances in Occurrence, Importance, and Mycotoxin Control Strategies: Prevention and Detoxification in Foods
}

\author{
Sofia Agriopoulou *, Eygenia Stamatelopoulou and Theodoros Varzakas \\ Department of Food Science and Technology, University of the Peloponnese, Antikalamos, 24100 Kalamata, \\ Greece; estamatel@gmail.com (E.S.); theovarzakas@yahoo.gr (T.V.) \\ * Correspondence: sagriopoulou@gmail.com; Tel.: +30-27210-45271
}

Received: 11 December 2019; Accepted: 22 January 2020; Published: 28 January 2020

check for updates

\begin{abstract}
Mycotoxins are toxic substances that can infect many foods with carcinogenic, genotoxic, teratogenic, nephrotoxic, and hepatotoxic effects. Mycotoxin contamination of foodstuffs causes diseases worldwide. The major classes of mycotoxins that are of the greatest agroeconomic importance are aflatoxins, ochratoxins, fumonisins, trichothecenes, emerging Fusarium mycotoxins, enniatins, ergot alkaloids, Alternaria toxins, and patulin. Thus, in order to mitigate mycotoxin contamination of foods, many control approaches are used. Prevention, detoxification, and decontamination of mycotoxins can contribute in this purpose in the pre-harvest and post-harvest stages. Therefore, the purpose of the review is to elaborate on the recent advances regarding the occurrence of main mycotoxins in many types of important agricultural products, as well as the methods of inactivation and detoxification of foods from mycotoxins in order to reduce or fully eliminate them.
\end{abstract}

Keywords: mycotoxins; occurrence; detoxification; decontamination; foodstuffs; aflatoxins; fumonisins; ochratoxins; food safety; risk

\section{Introduction}

Mycotoxins belong to the category of toxic secondary metabolites, and they have a low molecular weight. They are produced by filamentous fungi belonging to the phylum Ascomycota or molds, and they have great importance in the health of humans and animals, being the cause of acute and chronic diseases [1-4]. Bennett defined that mycotoxins are natural products produced by fungi that induce a toxic response when introduced at a low concentration to higher vertebrates and other animals via natural route [5]. The Greek word "mykes" meaning "fungi" and the Latin word "toxicum" meaning "poison" are the origin of the word mycotoxin [6]. A variety of fungi such as Aspergillus, Fusarium, Penicillium, Alternaria, and Claviceps spp. colonize their host and produce mycotoxins [7]. Of the approximately 400 compounds identified as mycotoxins, 30 receive great attention, and they are considered a threat to human or animal health [8]. The most important mycotoxins are aflatoxins (AFs) (represented mainly by aflatoxin B1 (AFB1), B2 (AFB2), G1 (AFG1), G2 (AFG2), M1 (AFM1)), ochratoxins (OTs) (represented mainly by ochratoxin A (OTA)), fumonisins (FBs) (represented mainly by fumonisins B1 (FB1), B2 (FB2), and B3 (FB3)), trichothecenes (TCs) (with type A represented by HT-2 toxin (HT2) and T-2 toxin (T2), and type B represented mainly by deoxynivalenol (DON)), zearalenone (ZEN), the emerging Fusarium mycotoxins (fusaproliferin (FP), moniliformin (MON), beauvericin (BEA), NX-2 toxin, and enniatins (ENNs)), ergot alkaloids (EAs), Alternaria toxins (ATs) (such as altenuene (ALT), alternariol (AOH), alternariol methyl ether (AME), altertoxin (ALTs), and tenuazonic acid (TeA)), and patulin (PAT). Mycotoxins cannot be detected by eye, but they can be seen under ultraviolet (UV) light; moreover, they have no characteristic odor and they do not alter the organoleptic characteristics of foods [9]. 
Certain mycotoxins are produced by more than one fungal species, while some fungi are capable of producing more than one mycotoxin. Moreover, more than one mycotoxin can be found on an infected substrate [10]. Favorable climatic conditions cause more fungal and mycotoxin contamination in developing and tropical countries than in developed and temperate ones [11].

Two groups of fungi producing mycotoxins in food exist: field fungi that infect crops before harvest, and storage fungi which occur only after harvest. Among toxicogenic field fungi, three types can be distinguished: plant pathogens such as Fusarium graminearum (deoxynivalenol producer) and F. verticillioides (fumonisin producer), fungi that grow on senescent or stressed plants such as Aspergillus flavus (aflatoxin producer), and fungi which initially colonize the plant before harvest and predispose the commodity to mycotoxin contamination after harvest such as Penicillium verrucosum (ochratoxin producer) and A. flavus [1].

Various factors affect both the growth and the production of mycotoxins in many types of fungi, including temperature, humidity, environment, $\mathrm{pH}$, water activity $\left(\mathrm{a}_{\mathrm{w}}\right)$, nutrients, level of inoculation, nature of the substrate, physiological state, and microbial interactions. This is why it is difficult for anyone to describe the set of optimal conditions for growth and production in physiological conditions [12]. Temperature $10-40{ }^{\circ} \mathrm{C}, \mathrm{pH} 8.4$, and $\mathrm{a}_{\mathrm{w}}$ at levels above 0.70 are the conditions in which fungi usually develop [13]. Field fungi typically need $70 \%-90 \%$ relative humidity, a temperature of $20-25{ }^{\circ} \mathrm{C}, \mathrm{a}_{\mathrm{w}}>0.85$ for active growth, and $\mathrm{a}_{\mathrm{w}}$ for optimal growth of 0.99 . Active growth is the phase when the fungus grows at high rates in the mycelium. On the contrary, storage fungi are adapted to lower humidity and higher temperatures. Most Aspergillus and Penicillium species require a minimum of $0.75-0.85 \mathrm{a}_{\mathrm{w}}$ and grow well at $0.93-0.98 \mathrm{a}_{\mathrm{w}}$. Aspergillus species require $\mathrm{a}_{\mathrm{w}}$ of 0.73 for active growth, while Penicillium species require $\mathrm{a}_{\mathrm{w}}$ of at least $0.78-0.80$. In addition, Aspergillus species adapt to temperatures of $30-40^{\circ} \mathrm{C}$, while Penicillium species exhibits good growth at temperatures of 25-30 ${ }^{\circ} \mathrm{C}[14]$.

Mycotoxins exist in agricultural commodities like peanuts [15], grapes and wines [3,16], grains [17,18], nuts, dried fruit, coffee, cocoa, spices, oil seeds, fruits, fruit juices, beer [14], and other foodstuffs and feed crops, both in the field and during transportation. At any stage of the food production process (before harvesting, harvesting, drying, and storage), fungal production of mycotoxins can occur and can expose consumers to the risk of contamination directly through food consumption or indirectly through feed [9]. In general, under prolonged storage conditions and at extreme temperatures along with extreme humidity, all crops including cereals can be subjected to mold growth and mycotoxin contamination [5]. The risk of producing mycotoxins increases with favorable conditions for fungal growth if bad farming and harvesting practices and inadequate drying, handling, packaging, storage, and transport conditions are applied [19].

Mycotoxicosis is the disease that results from exposure to mycotoxins (e.g., ergotism, alimentary toxic aleukia, aflatoxicosis), with effects on different organs of the human body, which can potentially cause death $[9,20]$ and can be categorized as acute or chronic [1]. Effects in humans and animals following direct exposure to mycotoxins vary in terms of their toxicity, e.g., carcinogenic, endocrine disorders, teratogenic, mutagenic, hemorrhagic, estrogenic, hepatotoxic, nephrotoxic, and immunosuppressive [21]. Contact, ingestion, and inhalation are the main ways of exposing mycotoxins to the human body [6].

The control of mycotoxin contamination is based on two strategies: prevention of their production and detoxification [21]. Conventional cooking processes cannot destroy all mycotoxins. For partial or complete elimination of mycotoxins from food, several methods related to food processing, and numerous physical, chemical, and biological methods are applied [22].

The purpose of this review is to present an overview of the main mycotoxins, as well as their diversity in appearance and their importance for the health of humans and livestock. Moreover, control, prevention, and decontamination/detoxification strategies for food control and management are studied both before and after harvesting. 


\section{Occurrence and Importance of Mycotoxins in Foods}

During different food processing technologies, including cooking, boiling, baking, frying, baking, and pasteurizing, most mycotoxins remain chemically and thermally stable. The result of contaminated feed is the presence of mycotoxins in animal foods such as meat, eggs, and milk, thereby leading to contamination of the human plate [3]. Regulatory limits on significant levels of mycotoxins in food and feed are established by various authorities worldwide such as the United States (US) Food and Drug Administration (FDA), the World Health Organization (WHO), the Food Agriculture Organization (FAO), and the European Food Safety Authority (EFSA) [5]. The International Agency of Research on Cancer (IARC) classifies some important mycotoxins into categories by examining the existence of sufficient human evidence for carcinogenicity, through toxicological studies [19]. Table 1 lists the major mycotoxins, their IARC number, the main producers, and some commonly contaminated foodstuffs, along with the US FDA and European Union (EU) regulatory limits for mycotoxin levels both in food and in animal feed [3,19].

The Rapid Alert System for Food and Feed (RASFF) monitors the contamination of food and feed by mycotoxins on a weekly basis in Europe. Through RASFF, all EU member states can be informed via an information exchange system and take measures to ensure the safety of food and feed [14]. Mycotoxins consistently constitute the highest risk category for notifications, and, every year, they are found among the "top ten" hazards reported annually by the RASFF. The records of the decade 2009-2018 [23-32] show that aflatoxins held the highest percentages (Table 2), while, based on the latest RASFF report for the year 2018 in the EU (Table 3), mycotoxin notifications amounted to 655, with aflatoxin notifications totaling 536, accounting for a significant proportion (82\%) [32]. Figure 1 presents the chemical structures of the main mycotoxins.

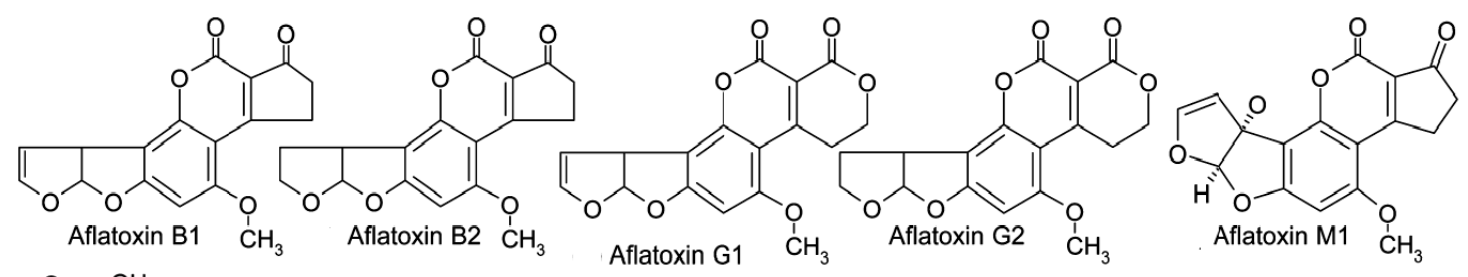<smiles>CC1Cc2c(Cl)cc(C(=O)NC(Cc3ccccc3)C(=O)O)c(O)c2C(=O)O1</smiles>

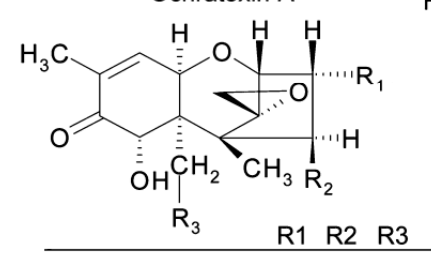

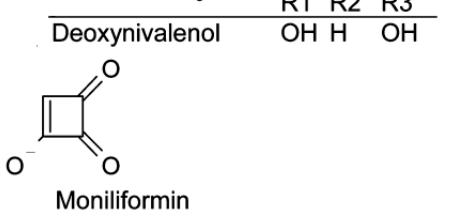

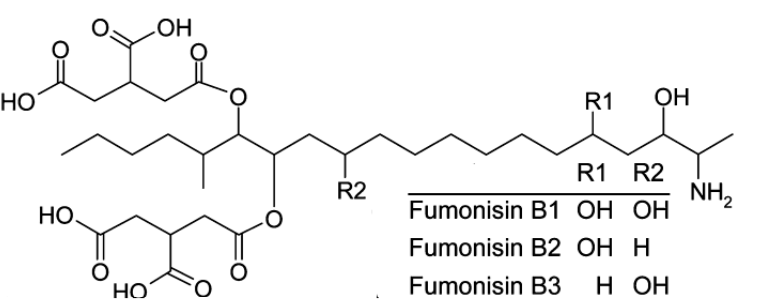<smiles>CCCCCC(=O)CCCC=Cc1cc(O)cc(O)c1C(=O)O</smiles><smiles>[R]C(C(=O)OC(C(=O)N(C)C(=O)C([R3])N(C)C(=O)C(C)C)C(=O)N(C)C([R])C(=O)OC(C(=O)O)C(C)C)C(C)C</smiles>

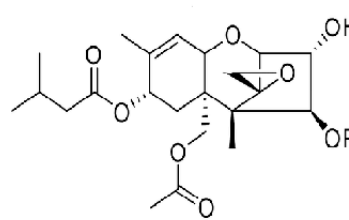<smiles>[R]c1cc(O)c2c(=O)oc3cc(O)cc([Y9])c3c2c1</smiles>

$R=A C \quad T-2$ toxin $\mathrm{R}=\mathrm{H} \quad \mathrm{HT}-2$ toxin

Enniatin A R1=R2=R3= $\mathrm{CH}\left(\mathrm{CH}_{3}\right) \mathrm{CH}_{2} \mathrm{CH}_{3}$ Enniatin A1 R1 =R2 $=\mathrm{CH}\left(\mathrm{CH}_{3}\right) \mathrm{CH}_{2} \mathrm{CH}_{3}, \mathrm{R} 3=\mathrm{CH}\left(\mathrm{CH}_{3}\right)_{2}$ Enniatin B R1=R2=R3= $\mathrm{CH}\left(\mathrm{CH}_{3}\right)_{2}$ Enniatin B1 R1 $=\mathrm{CH}\left(\mathrm{CH}_{3}\right) \mathrm{CH}_{2} \mathrm{CH}_{3}, \mathrm{R} 2=\mathrm{R} 3=\mathrm{CH}\left(\mathrm{CH}_{3}\right)_{2}$ Enniatin $\mathrm{B} 2 \mathrm{R} 1=\mathrm{R} 2=\mathrm{R} 3=\mathrm{CH}\left(\mathrm{CH}_{3}\right)_{2}$

Figure 1. Chemical structures of the main mycotoxins. 
The agricultural industry has to deal with the presence of mycotoxins in food, as it is of global importance and a major threat [33]. In developing countries, factors such as poor food quality control, hot climate, poor production technologies, and poor crop storage conditions favor the development of fungi and the formation of mycotoxins, resulting in the more frequent occurrence of mycotoxin-contaminated foods in these countries [34]. Huge agricultural and industrial losses in billions of dollars occur annually because $25 \%$ of the world's harvested crops are contaminated by mycotoxins [19]. The increased cost of production, the lowered animal production, the decreased market values, the irregularity of production [35], the regulatory enforcement, and the testing and other quality control measures [9] are some of the significant sources of economic loss due to the occurrence of mycotoxins in food and feed.

In the recent press release of the IARC and WHO in 2016, calls for action on mycotoxin contamination in developing countries were undertaken because, according to the report, on a daily basis, 500 million people in developing countries who are exposed to financial burdens are exposed to natural toxins, including mycotoxins, and, globally, 160 million children from developing countries under the age of five are stunted [36]. A search for the occurrence of major mycotoxins was made based on research in Scopus, ScienceDirect, Google Scholar, and Web of Science, between 2014 and 2019. 
Table 1. Most important mycotoxins and the United States (US) and European Union (EU) limits on food and animal feed levels. FDA-Food and Drug Administration; IARC-International Agency of Research on Cancer.

\begin{tabular}{|c|c|c|c|c|c|c|c|}
\hline Mycotoxin & IARC Number* & Acronym & Fungal Species & Food Commodity & US FDA $(\mu \mathrm{g} / \mathrm{kg})$ & $\mathrm{EU}(\mu \mathrm{g} / \mathrm{kg})$ & References \\
\hline Aflatoxins B1, B2, G1, G2 & $1^{*}$ & $\begin{array}{l}\text { AFB1 } \\
\text { AFB2 } \\
\text { AFG1 } \\
\text { AFG2 }\end{array}$ & $\begin{array}{c}\text { Aspergillus flavus, } \\
\text { Aspergillus parasiticus }\end{array}$ & $\begin{array}{l}\text { Maize, wheat, rice, } \\
\text { peanut, sorghum, } \\
\text { pistachio, almond, } \\
\text { ground nuts, tree nuts, } \\
\text { figs, cottonseed, spices }\end{array}$ & 20 for total & $\begin{array}{c}2-12 \text { for B1 } \\
4-15 \text { for total }\end{array}$ & [37] \\
\hline Aflatoxin M1 & $2 B^{*}$ & AFM1 & Metabolite of aflatoxin B1 & $\begin{array}{l}\text { Milk, milk products, } \\
\text { meat }\end{array}$ & 0.5 & $\begin{array}{c}0.05 \text { in milk } \\
0.025 \text { in infant } \\
\text { formulae and } \\
\text { infant milk }\end{array}$ & [37] \\
\hline Ochratoxin A & $2 B^{*}$ & OTA & $\begin{array}{l}\text { Aspergillus ochraceus, } \\
\text { Aspergillus carbonarius } \\
\text { Penicillium verrucosum, } \\
\text { Penicillium nordicum }\end{array}$ & $\begin{array}{l}\text { Cereals, dried vine } \\
\text { fruit, wine, grapes, } \\
\text { coffee, cocoa, cheese }\end{array}$ & Not set & $2-10$ & [37] \\
\hline Fumonisins B1, B2, B3 & $2 B^{*}$ & $\begin{array}{l}\text { FB1 } \\
\text { FB2 } \\
\text { FB3 }\end{array}$ & $\begin{array}{l}\text { Fusarium verticillioides, } \\
\text { Fusarium proliferatum }\end{array}$ & $\begin{array}{l}\text { Maize, maize } \\
\text { products, sorghum, } \\
\text { asparagus }\end{array}$ & $2000-4000$ & $200-4000$ & [38] \\
\hline Zearalenone & $3^{*}$ & ZEN & $\begin{array}{l}\text { Fusarium graminearum } \\
\text { (F. roseum), } \\
\text { Fusarium culmorum } \\
\text { Fusarium equiseti, } \\
\text { Fusarium cerealis, } \\
\text { Fusarium verticillioides, } \\
\text { Fusarium incarnatum }\end{array}$ & $\begin{array}{l}\text { Cereals, cereal } \\
\text { products, maize, } \\
\text { wheat, barley }\end{array}$ & Not set & $20-100$ & {$[38]$} \\
\hline $\begin{array}{c}\text { Trichothecenes } \\
\text { (type B: deoxynivalenol) }\end{array}$ & $3^{*}$ & DON & $\begin{array}{l}\text { Fusarium graminearum, } \\
\text { Fusarium culmorum, } \\
\text { Fusarium cerealis }\end{array}$ & $\begin{array}{l}\text { Cereals, cereal } \\
\text { products }\end{array}$ & 1000 & $200-50$ & {$[38,39]$} \\
\hline
\end{tabular}


Table 1. Cont.

\begin{tabular}{|c|c|c|c|c|c|c|c|}
\hline Mycotoxin & IARC Number * & Acronym & Fungal Species & Food Commodity & US FDA $(\mu \mathrm{g} / \mathrm{kg})$ & EU $(\mu \mathrm{g} / \mathrm{kg})$ & References \\
\hline Patulin & $3^{*}$ & PAT & $\begin{array}{l}\text { Penicillium expansum } \\
\text { Bysochlamis nívea, } \\
\text { Aspergillus clavatus, } \\
\text { Penicillium patulum } \\
\text { Penicillium crustosum }\end{array}$ & $\begin{array}{l}\text { Apples, apple juice, } \\
\text { and concentrate, pears, } \\
\text { peaches, grapes, } \\
\text { apricots, olives low } \\
\text { acid fruit juices }\end{array}$ & 50 & $10-50$ & {$[37,40]$} \\
\hline $\begin{array}{l}\text { Trichothecenes } \\
\text { (type A: HT-2) }\end{array}$ & $3^{*}$ & HT2 & $\begin{array}{c}\text { Fusarium langsethiae, } \\
\text { Fusarium sporotrichioides }\end{array}$ & $\begin{array}{l}\text { Maize, wheat, barley, } \\
\text { oat, rye }\end{array}$ & 15 & $25-1000$ & [41] \\
\hline $\begin{array}{l}\text { Trichothecenes } \\
\text { (type A: T-2 toxin) }\end{array}$ & $3^{*}$ & $\mathrm{~T}-2$ & $\begin{array}{c}\text { Fusarium langsethiae, } \\
\text { Fusarium sporotrichioides }\end{array}$ & $\begin{array}{l}\text { Maize, wheat, barley, } \\
\text { oat, rye }\end{array}$ & 15 & $25-1000$ & {$[41]$} \\
\hline Enniatins & & ENNs & $\begin{array}{l}\text { Fusarium tricinctum, } \\
\text { Fusarium avenaceum }\end{array}$ & Corn & Not set & Not set & {$[21]$} \\
\hline Ergot alkaloids & & EAs & $\begin{array}{l}\text { Claviceps purpurea, } \\
\text { Claviceps fusiformis, } \\
\text { Claviceps africana, } \\
\text { Neotyphodium spp }\end{array}$ & $\begin{array}{l}\text { Rye, rye-containing } \\
\text { commodities, wheat, } \\
\text { triticale, barley, millet } \\
\text { and oat }\end{array}$ & Not set & Not set & {$[19,42]$} \\
\hline Alternariol & & $\mathrm{AOH}$ & Alternaria alternata & $\begin{array}{l}\text { Grain and grain-based } \\
\text { products, vegetables } \\
\text { and vegetable } \\
\text { products, } \\
\text { fruits and fruit } \\
\text { products, wine and } \\
\text { beer, oilseeds and } \\
\text { vegetable oils }\end{array}$ & Not set & Not set & [43] \\
\hline
\end{tabular}


Table 2. Mycotoxin notification in the EU during the decade 2009-2018 (Rapid Alert System for Food and Feed (RASFF), Annual Report, 2009-2018) [23-32].

\begin{tabular}{ccccccccccc}
\hline Mycotoxins & $\mathbf{2 0 0 9}$ & $\mathbf{2 0 1 0}$ & $\mathbf{2 0 1 1}$ & $\mathbf{2 0 1 2}$ & $\mathbf{2 0 1 3}$ & $\mathbf{2 0 1 4}$ & $\mathbf{2 0 1 5}$ & $\mathbf{2 0 1 6}$ & $\mathbf{2 0 1 7}$ & $\mathbf{2 0 1 8}$ \\
\hline Aflatoxins & 638 & 649 & 585 & 484 & 341 & 314 & 438 & 348 & 529 & 536 \\
Deoxynivalenol (DON) & 3 & 2 & 11 & 4 & 8 & 6 & 11 & & & \\
Fumonisins & 1 & 3 & 4 & 4 & 7 & 3 & 5 & & & \\
Ochratoxin A & 27 & 34 & 35 & 32 & 54 & 38 & 42 & 141 & & 33 \\
Patulin & & & & & & & 2 & & & \\
Zearalenone & & & & 4 & & 3 & 2 & & & \\
Total & 669 & 688 & 635 & 525 & 410 & 364 & 500 & 489 & 529 & 569 \\
\hline
\end{tabular}

Table 3. Notifications by hazard category in the EU in 2018 (RASFF, Annual Report, 2018) [32]. GMO—genetically modified organism.

\begin{tabular}{ccccc}
\hline Hazard Category & Alert & Border Rejection & Information for Attention & Information for Follow-Up \\
\hline Allergens & 158 & 11 & 35 & 3 \\
Biological contaminants (other) & 22 & 4 & 20 & 35 \\
Food additives and flavorings & 19 & 64 & 19 & 33 \\
Foreign bodies & 106 & 10 & 1 & 3 \\
GMO food or feed & & 9 & 65 & 22 \\
Novel food & 8 & 13 & 55 & 9 \\
Metals & 56 & 508 & 17 & 4 \\
Industrial contaminants & & 1 & 191 & 23 \\
Mycotoxins & 88 & 302 & 60 & 137 \\
Parasitic infestation & & 154 & 15 & 14 \\
Pathogenic microorganisms & 349 & 15 & & 8 \\
Pesticides residues & 48 & & & \\
Residues of veterinary medicinal products & 10 & & & \\
\hline
\end{tabular}

\subsection{Aflatoxins}

Aflatoxins are secondary metabolites, and they belong to the category of difuranocoumarins [44]. Under warm and humid conditions, Aspergillus flavus, A. nomius, and A. parasiticus produce AFs [22,45], commonly found in food and feeds. The species A. flavus and A. parasiticus are found worldwide in the soil and in the air [46], preferring to grow at temperatures between 22 and $35^{\circ} \mathrm{C}$ and $\mathrm{a}_{\mathrm{w}}$ between 0.95 and 0.98 [47]. Other species producing aflatoxins similar to $A$. flavus are $A$. zhaoqingensis and A. bombycis, while those similar to A. parasiticus are A. toxicarius and A. parvisclerotigenus. Moreover, A. pseudotamarii, A. ochraceoroseus, A. rambellii, A. toxicarius, Emericella astellata, E. olivicola, and E. venezuelensis are some species of mycotoxin producers. Two other recently described aflatoxigenic species are $A$. minisclerotigenes and A. arachidicola [48].

AFs are the best known among all mycotoxins, because of their serious impact on human and animal health. Four main types of aflatoxins are the most studied among more than 20 known ones; these are aflatoxin AFB1, AFB2, AFG1, and AFG2, named after the fluorescence they display in UV light (B for blue and $G$ for green). The hydroxylated metabolites of AFB1 and AFB2 are aflatoxin M1 (AFM1) and aflatoxin M2 (AFM2), which are present in the meat of animals that consumed aflatoxin-contaminated feed, as well as animal products such as eggs, milk, and cheese [22]. Aflatoxin B1 is a carcinogenic substance (according to the classification by the IARC in 1987) (category 1A), while AFM1 is a potentially carcinogenic substance (category 2B) [49], with a toxicity range of B1 > G1 > B2 > G2 [50]. AFB1 is considered to be the most potent carcinogenic toxin known in mammals [51], and food contamination should be reduced to the lowest possible level, since no food or health organization established a tolerable daily intake for humans (tolerable daily intake, TDI) [52]. Exposure to chronic hepatitis B virus infection and aflatoxin may increase liver cancer risk by up to 30 times compared to the risk in individuals exposed to aflatoxin only [53]. The risk of exposure to contaminated foods with varying levels of AFs worldwide exists for more than 4.5 billion people [54]. At present, levels of AFs in food and feed are established in approximately 100 countries [55]. The EU legal limit for AFB1 in processed cereal foods is $0.02 \mu \mathrm{g} / \mathrm{kg}$ [56]. Different maximum upper limits are set worldwide for AFM1 in milk or milk products, with Codex Alimentarius and the EU setting the limit to $0.05 \mu \mathrm{g} / \mathrm{kg}$ AFM1, whereas the US and some Latin American countries set it to $0.5 \mu \mathrm{g} / \mathrm{kg}$ [57]. 
Aflatoxins are the first mycotoxins to be initially classified as toxic, following research into the deaths of 100,000 poultry (mainly turkeys) in England. Originally, the causes of the strange disease at that time were unknown; thus, the disease was named " $X$ disease ", that is, turkey $X$ disease. It was later found that the cause was the growth of A. flavus in poultry feed. This led to a breakthrough in the research on the field of mycotoxins, which in turn led to the intensive and systematic checks on any moldy product and setting maximum limits [9].

Pre-harvest and post-harvest factors are related to the production of AFs. Thus, pre-harvest weather conditions associated with periods of drought and heat stress during flowering and fruit growth were reported to be the main factors responsible for the increased infection with AFs produced by A. flavus and A. parasiticus in maize, pistachio, cotton, and nuts [58]. Furthermore, other stress factors in plants, such as inadequate nutrition, insect nutrition from growing fruits, weed competition, overgrowth of plants, and plant diseases, facilitate fungal infection and the production of AFs [58]. After harvesting, higher concentrations of AFs are observed due to improper storage of the products, such as storage with inadequate moisture content and inappropriate temperature. If the product is quickly dried and stored under appropriate conditions, and the $\mathrm{a}_{\mathrm{w}}$ value does not exceed 0.78 , aflatogenic molds do not grow well. The biosynthesis of AFs is inhibited at an $\mathrm{a}_{\mathrm{w}}$ of less than 0.8334 . Because the production of AFs depends on the $a_{w}$ interaction with temperature, maintaining the temperature in the storage area below $15{ }^{\circ} \mathrm{C}$ leads to minimum $\mathrm{a}_{\mathrm{w}}$ for the production of mycotoxins at 0.934. Moreover, the formation of AFs can cause damage to the products [59].

Aflatoxins are linked to various diseases, such as aflatoxicosis, in animals, pets, and humans around the world [44], and they are considered to be particularly harmful as they have carcinogenic, mutagenic (DNA damaging), teratogenic, and immunosuppressive effects [51]. Symptoms of acute aflatoxicosis in humans include vomiting, abdominal pain, jaundice, pulmonary edema, coma, convulsions, and death $[5,60]$, while chronic aflatoxicosis occurs via cancer, immune system inhibition, and liver damage. There are significant differences in species sensitivity, with the size of the reaction depending on a variety of factors, such as age, sex, weight, nutrition, metabolism, exposure to infectious agents, and the occurrence of other mycotoxins [5], as well as the type of toxin, mechanism of action, and levels of intake [61]. In many areas of the world, where liver cancer occurs in large numbers in the population (e.g., in southeast Asia and sub-Saharan Africa), chronic hepatitis $C$ infection and aflatoxin exposure are considered important risk factors, since they are likely to interact synergistically [62].

In India, the most serious outbreak of human hepatitis was recorded in 1974, when 108 of 397 patients died after consuming heavily contaminated maize with AFs at levels of $0.25-15 \mathrm{mg} / \mathrm{kg}$ [63], while the largest and most serious case of acute aflatoxin poisoning in humans worldwide, recorded in April 2004 in Kenya, resulted in 125 out of 317 patients losing their lives (mortality rate, 39.4\%) after eating infected maize, with aflatoxin levels of $5-20 \mathrm{mg} / \mathrm{kg}$ [64]. A smaller-scale epidemic occurred in Kenya in 2005, causing 16 deaths [65], while, in the same country in 1981, 12 deaths were recorded from consumption of contaminated maize at levels of 3.2-12 mg/ $\mathrm{kg}$ with AFB1 [64]. In addition, encephalopathy and visceral degeneration in children are symptoms of Reye's syndrome, which is linked to aflatoxin toxicity [19].

Aflatoxin contamination was reported in various countries such as Argentina [66], Brazil [67], China [68], Italy [69], Portugal [70], Spain [71], and Tanzania [72]. In food analysis, the presence of AFB1 is often the highest in the AF mixture [19]. AFs are mainly detected in cereals (barley, corn, rice, wheat, oat) [33] and their derivatives (bread, flour, breakfast products, cornflakes and pasta) [4], in nuts (almonds, pecans, pistachios, walnuts, cashews, and Brazil nuts) and peanuts [73], in species and herbs [6,74], in edible vegetable oils [55], in wines [75], in sugarcane [76], in cottonseed [40], in dried fruits [77], and in animal food products such as milk [78], eggs [79], cured meat [80], and animal tissues [81]. Some detailed recent studies on AF occurrence in foods are presented in Table 4. The problem of AFs is very important around the world and particularly in Africa, where aflatoxin contamination is reported in raw cereals with $50 \%$ incidence, with infestation reaching $1642 \mu \mathrm{g} / \mathrm{kg}$ in rice [33]. 
Table 4. Representative studies on the occurrence of aflatoxin (AF) distribution ( $\mu \mathrm{g} / \mathrm{kg})$ in food samples around the world during $2014-2019$.

\begin{tabular}{|c|c|c|c|c|c|c|c|c|}
\hline Country & Food Matrix & AFs & $N$ Samples & Incidence $\%$ & Mean $\mu \mathrm{g} / \mathrm{kg}$ & Range $\mu \mathrm{g} / \mathrm{kg}$ & Detection Technique & Reference \\
\hline China & Raw milk & AFM1 & 530 & 52.8 & 0.07 & $0.01-0.2$ & LC-MS/MS & [82] \\
\hline Nigeria & Breast milk & AFM1 & 40 & 77 & 0.066 & $0.001-0.601$ & HPLC & [83] \\
\hline Burkina Faso & Infant formula & AFB1 & 199 & 84 & 3.8 & $0-87.4$ & HPLC & [84] \\
\hline \multirow{4}{*}{ China } & \multirow{4}{*}{ Wheat } & AFB1 & 348 & 0.28 & 7.3 & $<0.10-7.3$ & \multirow{4}{*}{ LC-MS/MS } & \multirow{4}{*}{ [85] } \\
\hline & & AFB2 & 348 & 0.28 & 1.2 & $<0.10-1.2$ & & \\
\hline & & AFG1 & 348 & 0 & - & - & & \\
\hline & & AFG2 & 348 & 0 & - & - & & \\
\hline \multirow{2}{*}{ China } & \multirow{2}{*}{ Rice } & AFB1 & 370 & 63.50 & 0.6 & $0.03-20.0$ & \multirow{2}{*}{ HPLC } & \multirow{2}{*}{ [86] } \\
\hline & & AFB2 & 370 & 17.57 & 0.2 & $<0.1-3.2$ & & \\
\hline China & Maize & AFB1 & 44 & 2.3 & 148.4 & - & HPLC & [87] \\
\hline Turkey & Walnut & AFs & 48 & 44 & 1.33 & $0.58-15.2$ & HPLC & [88] \\
\hline \multirow{4}{*}{ Turkey } & Seedless black raisins & \multirow{4}{*}{ AFs } & 25 & 64 & 0.4 & $0.02-2.07$ & \multirow{4}{*}{ HPLC } & \multirow{4}{*}{ [89] } \\
\hline & Dried figs & & 45 & 51 & 1.78 & $0.16-5.20$ & & \\
\hline & Ground red peppers & & 25 & 72 & 2.30 & $0.04-3.47$ & & \\
\hline & Walnuts without shell & & 25 & 64 & 1.68 & $0.66-2.62$ & & \\
\hline Nigeria & Ginger & AFs & 120 & 81 & 3.13 & $0.11-9.52$ & HPLC & [90] \\
\hline \multirow{2}{*}{ Egypt } & \multirow{2}{*}{ Dried date palm } & AFB1 & \multirow{2}{*}{28} & \multirow{2}{*}{4} & \multirow{2}{*}{-} & 14.4 & \multirow{2}{*}{ LC-MS/MS } & \multirow{2}{*}{ [77] } \\
\hline & & AFB2 & & & & 2.44 & & \\
\hline Tanzania & Sun-dried sweet potato chips & AFs & 80 & 36 & 40.31 & $10.49-75.12$ & HPLC & [91] \\
\hline Ghana & Cereal-based products & AFs & 50 & 72 & - & $0.18-25.93$ & HPLC & {$[56]$} \\
\hline Czech Republic & Barley and malt samples & AFs & 52 & $\mathrm{Nd}^{\mathrm{a}}$ & - & - & LC-MS/MS & [92] \\
\hline
\end{tabular}

${ }^{\mathrm{a}} \mathrm{Nd}$-not detected. 


\subsection{Ochratoxin $A$}

Among the ochratoxin categories A, B, and C, OTA is the most abundant and harmful mycotoxin that contaminates foods [93]. OTA was first identified in South Africa, from the fungus A. ochraceus, from which it derives its name. It is chemically known as the phenylalanyl derivative of a substituted iso-coumarin ( $R$ )- $\mathrm{N}$-[5-chloro-3,4-dihydro-8-hydroxy-3-methyl-1-oxo-1H-2-benzopyran-7-y1] carbonyl]-L phenylalanine [94]. Aspergillus and Penicillium are the two main genera of OTA producers. The main producing species belong to the Aspergillus section Circumdati, Aspergillus section Nigri, P. verrucosum, P. thymicola, and P. nordicum [19]. The non-chlorinated analogue, ochratoxin B, which is much less toxic, sometimes co-occurs with OTA in food and feed [53]. Although OTA produced by Aspergillus can likely occur pre-harvest, recent studies [95] pointed to OTA in grains as mainly a storage issue.

Ochratoxin is linked to immunotoxic, genotoxic, neurotoxic, carcinogenic, nephrotoxic, and teratogenic effects, considered the most toxic ones among the ochratoxin family members. Moreover, it is classified by the IARC as a possible human carcinogen (Group 2B) [20], but the specific mechanism of toxicity is not fully understood. Increased incidence of testicular cancer in animals is associated with ingestion of OTA [19]. Although OTA is liable to decomposition in the rumen, it was found in cow's milk [96]. The mutagenic capacity of AFB1 could be increased in cases of co-occurrence with OTA in some crops [97]. A provisional tolerable weekly intake (PTWI) of $112 \mathrm{ng} / \mathrm{kg}$ body weight (b.w.) was proposed by the Joint FAO/WHO Expert Committee on Food Additives (JEFCA) [98].

Ochratoxin production is observed in the $\mathrm{a}_{\mathrm{w}}$ range of $0.92-0.99$, with the maximum concentration being in the range $0.95-0.99$ depending on the strains. The optimum temperature for OTA production is $20^{\circ} \mathrm{C}$, followed by the temperature of $15^{\circ} \mathrm{C}$, with significantly lower production at $30-37^{\circ} \mathrm{C}$ [99]. Taking into account that Aspergillus and Penicillium responsible for the production of OTAs have a temperature range of $12-37^{\circ} \mathrm{C}$ for $A$. ochraceus and $0-31{ }^{\circ} \mathrm{C}$ for $P$. verrucosum, OTA can be produced in all agricultural areas of the world [33].

Ochratoxin was reported in cereals [28], in species [6], in alcoholic beverages such as in wines [75] and in beer [100], in dried vine fruits [40], in coffee [101], in cocoa and chocolate [102,103], in meat [104], and in milk [96]. Among foods, cereals occupy the first position of the total exposure to OTAs with $60 \%$ [105]. The maximum limits of $5 \mathrm{ng} / \mathrm{g}$ OTA in raw cereal grains, $3.0 \mathrm{ng} / \mathrm{g}$ in cereal-processed products, $10 \mathrm{ng} / \mathrm{g}$ in coffee and dried fruits, $2 \mu \mathrm{g} / \mathrm{L}$ in wine, and $0.5 \mathrm{ng} / \mathrm{g}$ in cereal-based baby foods are set by European commission (EU) [106].

Pig's blood, kidney, liver muscle, and adipose tissue are some of the tissues where OTA was detected with rather high levels found in animals suffering from porcine nephropathy, especially in countries of the Balkan Peninsula [53]. In a human disease of kidney referred to as Balkan endemic nephropathy, OTA is implicated. The disease is characterized by tubule interstitial nephritis, and OTA is associated with a high incidence of kidney, pelvis, ureter, and urinary bladder tumors in some eastern European countries [51]. It is also suspected that the inhalation of OTs via air and dust caused by the opening of Egyptian tombs may have led to the deaths of archaeologists [6].

Recent OTA studies in food commodities are presented in Table 5. 
Table 5. Representative studies on the occurrence of ochratoxin A (OTA) distribution $(\mu \mathrm{g} / \mathrm{kg}$ or $\mu \mathrm{g} / \mathrm{L})$ in food samples around the world during $2014-2019$.

\begin{tabular}{|c|c|c|c|c|c|c|c|}
\hline Country & Food Matrix & $N$ Samples & Incidence \% & Mean $\mu \mathrm{g} / \mathrm{kg}$ & Range $\mu \mathrm{g} / \mathrm{kg}$ & Detection Technique & Reference \\
\hline China & Dried vine fruits & 56 & 58.9 & 0.99 & $<0.07-12.83$ & HPLC & [107] \\
\hline China & Dried fruits & 220 & 5 & 1.9 & $0.2-8.8$ & LC-MS/MS & [108] \\
\hline China & Rice & 370 & 4.87 & 0.9 & $0.30-3.2$ & HPLC & {$[86]$} \\
\hline Burkina Faso & Infant formula & 199 & 7.5 & 0.1 & $0-3.2$ & HPLC & [84] \\
\hline \multirow{2}{*}{ Syria } & Fruit-based products & 12 & 33 & 0.093 & $0.019-0.156$ & \multirow{2}{*}{ HPLC } & \multirow{2}{*}{ [109] } \\
\hline & Cereal-based baby food & 30 & 43 & 0.094 & $0.02-0.329$ & & \\
\hline Brazil & Breast milk & 86 & 0 & - & - & LC-MS/MS & [110] \\
\hline \multirow{2}{*}{ Turkey } & Eggplant & \multirow{2}{*}{50} & \multirow{2}{*}{100} & 17.67 & $8.88-21.35$ & \multirow{2}{*}{ HPLC } & \multirow{2}{*}{ [111] } \\
\hline & Green bell pepper & & & 20.53 & $15.38-24.70$ & & \\
\hline Egypt & Dried date palm & 28 & 11 & 58.7 & $1.48-6070$ & LC-MS/MS & [77] \\
\hline Lebanon & Spices & 94 & 30 & 7.1 & $2-33.9$ & LC-MS/MS & [74] \\
\hline Czech Republic & Barley and malt samples & 52 & $\mathrm{Nd}^{\mathrm{a}}$ & - & - & LC-MS/MS & [92] \\
\hline Syria & Durum wheat & 40 & 30 & 0.6 & $0.4-0.7$ & LC-MS/MS & [112] \\
\hline Qatar & Baby food, cereal based & 51 & 31 & $\mathrm{NA}^{\mathrm{b}}$ & $0.05-\geq 0.50$ & LC-MS/MS & [114] \\
\hline $\begin{array}{c}\text { Kingdom of Saudi } \\
\text { Arabia }\end{array}$ & Cardamom & 80 & 48 & $\mathrm{NA}^{\mathrm{b}}$ & $30-78$ & HPLC & [115] \\
\hline \multirow{2}{*}{ Portugal } & Roasted coffee & 6 & 33 & $1.84 \mu \mathrm{g} / \mathrm{Kg}$ & LOD-10.31 & \multirow{2}{*}{ HPLC } & \multirow{2}{*}{ [116] } \\
\hline & Ground roasted coffee & 5 & 20 & $1.45 \mu \mathrm{g} / \mathrm{Kg}$ & LOD-7.26 & & \\
\hline $\begin{array}{l}\text { Denmark, Kenya, } \\
\text { Tanzania, Uganda }\end{array}$ & Roasted coffee & 57 & 46 & $\mathrm{NA}^{\mathrm{b}}$ & 2.3 & UHPLC-MS/MS & [117] \\
\hline
\end{tabular}

${ }^{\mathrm{a}} \mathrm{Nd}-$ not detected. ${ }^{\mathrm{b}} \mathrm{NA}-$ not available in the publication. 
Risk assessments were carried out based on OTA occurrence data in Brazil [118], Benin, Cameroon, Mali, Nigeria [119], and Paraguay [103]. According to these studies, the majority of the population did not exceed the TDI.

The impact of OTA in recent research shows the importance of reinforcing OTA control strategies in food production. Although mycotoxins are extremely stable during food processing, there are several factors that can affect their stability [6]. At different stages of food processing such as baking, roasting, frying, brewing, canning, and peeling, OTA cannot be completely deactivated [120]. Moreover, it was reported that OTA can be transferred into beer and wine samples from contaminated grains [121]. Feeding animals with OTA-infected bread can cause its accumulation in the meat of animals intended for human consumption [122].

\subsection{Fumonisins}

Fumonisins belong to a large group of toxins referred to as Fusarium toxins, which occur in cereals originating from pathogenic fungi, mostly Fusarium verticillioides and Fusarium proliferatum [123]. In addition, Aspergillus niger can produce fumonisins on grapes and raisins [124]. The group of 28 analogues of FBs is divided into four main groups: fumonisin A, B, C, and P. In addition to A, B, $\mathrm{C}$, and $\mathrm{P}$, there is also Fumonisins "Py" that can occur [123]. The fumonisin B (FB) analogues, which include FB1, FB2, and FB3, occur in nature with the highest frequency, whereas FB1 is usually found at the highest concentrations [125]. Fumonisins cause health effects in animals, especially in the liver and kidney, although data for the health effects of fumonisins in humans remain limited [126]. FB1 can cause leukoencephalomalacia in horses [127], and pulmonary edema syndrome and hydrothorax in pigs [128].

The IARC classifies FB1 and FB2 as possibly carcinogenic to humans (Group 2B) [20], and the JECFA set a provisionally maximum tolerable daily intake (PMTDI) of $2 \mu \mathrm{g} / \mathrm{kg}$ b.w./day for FB1, FB2, and FB3 alone or in combination [129]. Acceptable upper limits of 800-4000 and 2000-4000 $\mu \mathrm{g} / \mathrm{kg}$ FB1 and FB2, respectively, were set by the European Union [38] (EU Regulation 1126/2007) and the US, in cereal-based products [130].

Fumonisins contaminate cereals [131] and their derivatives [132,133], and they also exist in maize and maize-based products [134], asparagus [135], grapes, and raisins [124]. Table 6 presents representative studies on the occurrence of FUs $(\mu \mathrm{g} / \mathrm{kg})$ in food samples worldwide during 2014-2019. 
Table 6. Representative studies on the occurrence of fumonisin (FU) distribution ( $\mu \mathrm{g} / \mathrm{kg}$ ) in food samples around the world during $2014-2019$.

\begin{tabular}{|c|c|c|c|c|c|c|c|c|}
\hline Country & Food Matrix & Fumonisins & $N$ Samples & Incidence \% & Mean $\mu \mathrm{g} / \mathrm{kg}$ & Range $\mu \mathrm{g} / \mathrm{kg}$ & Detection Technique & Reference \\
\hline China & Maize & FB1 & 44 & 100 & 116.5 & $16.5-315.9$ & HPLC & [89] \\
\hline Burkina Faso & Infant formula & FB1 + FB2 & 199 & 1.5 & 30.3 & $0-672.9$ & HPLC & [86] \\
\hline \multirow{2}{*}{ United States } & \multirow{2}{*}{$\begin{array}{l}\text { Infant cereal-based } \\
\text { products }\end{array}$} & FB1 & \multirow{2}{*}{64} & 2 & \multirow{2}{*}{ NA } & $<$ LOD-6.2 & \multirow{2}{*}{ LC-MS/MS } & \multirow{2}{*}{ [136] } \\
\hline & & FB2 & & 8 & & $<$ LOD-15.8 & & \\
\hline Egypt & Dates palm & FB2 & 28 & 7 & 10.6 & $4.99-16.2$ & LC-MS/MS & [77] \\
\hline Serbia & Crop maize & FUs & 90 & 100 & 1730 & $520.0-5800.0$ & ELISA & [137] \\
\hline \multirow{3}{*}{ China } & \multirow{3}{*}{ Corn flakes } & FB1 & 14 & 100 & 104.1 & $1.0-171.0$ & \multirow{3}{*}{ UPLC-MS-MS } & \multirow{3}{*}{ [138] } \\
\hline & & FB2 & 14 & 93 & 14.2 & $<0.27-25.6$ & & \\
\hline & & FB3 & 14 & 93 & 17.3 & $<0.27-31.5$ & & \\
\hline \multirow{2}{*}{ Lebanon } & \multirow{2}{*}{ Spices } & FB1 & \multirow{2}{*}{94} & 64 & 6432.3 & $18.2-113474.5$ & \multirow{2}{*}{ LC-MS/MS } & \multirow{2}{*}{ [74] } \\
\hline & & FB2 & & 35 & 230.2 & $15.1-1757.4$ & & \\
\hline Argentina & $\begin{array}{l}\text { Wheat-based } \\
\text { products }\end{array}$ & $\mathrm{FB} 1+\mathrm{FB} 2$ & 91 & 74 & 1.54 & $0.05-18.9$ & HPLC-MS/MS & [132] \\
\hline China & Wheat flour & FB1 & 369 & 6.2 & NA & $0.3-34.6$ & UPLC-MS/MS & [138] \\
\hline Tanzania & $\begin{array}{l}\text { Sun-dried sweet } \\
\text { potato chips }\end{array}$ & FB1 & 80 & 97.5 & 44.69 & $29.34-628.78$ & HPLC & [91] \\
\hline Brazil & Wheat cultivars & FB1 & 11 & 54 & 2814.33 & 958-4906 & HPLC & [139] \\
\hline \multirow{4}{*}{ Argentina } & Wheat & \multirow{2}{*}{ FB1 } & 135 & 97 & 30.07 & $0.16-680.4$ & \multirow{4}{*}{ HPLC-MS/MS } & \multirow{4}{*}{ [133] } \\
\hline & Durum wheat & & 40 & 77.5 & 84.75 & $0.15-1304.4$ & & \\
\hline & Wheat & \multirow{2}{*}{ FB2 } & 135 & 51 & 2.88 & $0.25-23.7$ & & \\
\hline & Durum wheat & & 40 & 42.5 & 10.47 & $0.43-47$ & & \\
\hline Italy & Durum wheat & FB1 & 4 & 100 & 33 & $15-51$ & HPLC-MS/MS & [140] \\
\hline Syria & Durum wheat & FB1 & 40 & 10 & 5 & $5-6$ & HPLC-MS/MS & [112] \\
\hline
\end{tabular}

${ }^{\mathrm{a}}$ NA—not available in the publication. 


\subsection{Trichothecenes}

Trichothecenes are produced by different species of Fusarium, Myrothecium, Trichoderma, Trichothecium, Cephalosporium, Verticimonosporium, and Stachybotrys [53]. These cyclic sesquiterpenoid toxins are characterized by a variable number of acetoxy and hydroxyl groups, an epoxide ring at position $C_{12}-C_{13}$, and a double bond between $C_{9}$ and $C_{10}$ [141]. TCs are easily absorbed into the gastrointestinal membranes and are rapidly distributed to various organs and tissues of the body because of their low molecular weight and amphipathic nature [40]. More than 200 different TCs are known at present, subdivided into four basic groups: A, B, C, or D. The most toxic groups of trichothecenes are type A (T-2 and HT-2) compared to type B analogues (e.g., nivalenol (NIV), DON, and fusarenon-X (FX)) [142].

\subsubsection{Trichothecenes Type A (HT-2 Toxin and T-2 Toxin)}

The main fungal species producing HT-2 and T-2 toxins is Fusarium langsethiae. Fusarium poae, Fusarium sporotrichioides, F equiseti, and F. acumninatum were also found to produce T-2 and HT-2 [143,144].

HT-2 and T-2 toxins are found in oat, barley, wheat, maize, and rice, as well as in cereal-based products and soybean $[53,98]$. HT-2 and T-2 toxins show toxic effects such as growth retardation, myelotoxicity, hematotoxicity, and necrotic lesions on contact sites [145]. A TDI of $100 \mathrm{ng} / \mathrm{kg}$ b.w./day for T-2 and HT-2 toxins was set by the EFSA [144].

\subsubsection{Trichothecenes Type B (Deoxynivalenol)}

Deoxynivalenol, also denoted as vomitoxin, is produced by fungi of the Fusarium genus, mainly by Fusarium graminearum and F. culmorum, which are both associated with FHB disease (Fusarium head blight) in cereals, especially oats, barley, wheat rye, and maize, and less frequently in rice, sorghum, and triticale [17,146]; it also contaminated cereal-derived food products such as bread, pasta, or beer. DON is the predominant trichothecene all over the world, although it is among the least toxic of the trichothecenes, and its occurrence is considered to be an indicator of the potential presence of other, more toxic trichothecenes [53]. DON is the most frequently detected mycotoxin in cereal grains worldwide. The average incidence is 59\%, with 50\% and 76\% in Asia and Africa, respectively, with a tendency for higher concentrations in Europe and Asia [33]. Moreover, levels of DON in grains (wheat, maize, and barley) in North America do not appear to be different from those reported around the world, and they can be much higher than usual in certain years due to more severe Fusarium infection [147].

The maximum level of DON of $200 \mu \mathrm{g} / \mathrm{kg}$ was set by the EU in cereal-based baby foods for infants and young children, as well as levels of $750 \mu \mathrm{g} / \mathrm{kg}$ in flour and $500 \mu \mathrm{g} / \mathrm{kg}$ in breads [146]. At high temperatures, DON is a very stable trichothecene $\left(120^{\circ} \mathrm{C}\right.$, moderately stable at $\left.180{ }^{\circ} \mathrm{C}\right)$, as well as soluble in water and in polar solvents such as aqueous methanol, acetonitrile, and ethyl acetate [148], and it is found during the storage and processing of products [100]. The DON effect of protein synthesis inhibition is through binding to the ribosomal subunit, leading to ribotoxic stress [149]. The most common route of exposure to DON is through food. Acute gastrointestinal symptoms such as vomiting, hemorrhagic diarrhea, and refusal of food may occur in animals after ingestion of highly contaminated animal feed. Symptoms such as anorexia, suppression of body weight gain, hepatotoxicity, dermatological problems, and altered nutritional efficacy appear after long-term dietary exposure to DON. The acute effects of DON on animals and humans are similar [17]. Consumption of DON-contaminated cereals was linked to acute gastroenteritis and emesis in India [2]. The mutagenic 
and/or carcinogenic properties of DON are not established by experimental or epidemiological evidence and, therefore, the IARC classifies DON as not carcinogenic to humans (Group 3) [49]. The FAO/WHO and JECFA established a PMTDI of $1 \mathrm{mg} / \mathrm{kg}$ b.w. for the sum of DON and its acetyl derivatives (3-ADON and 15-ADON) [150]. A PMTDI of $1 \mu \mathrm{g} / \mathrm{kg}$ b.w./day for DON and its metabolites, 3-ADON, 15-ADON, and DON-3-glucoside (DON-3G), was set recently by the EFSA [151].

The occurrence of DON is reported in various countries such as Paraguay [100], Lebanon [74], Nigeria [152], China [148], Tunisia [153], Croatia [154], and Morocco [155]. Representative studies on the occurrence with DON, HT-2, and T-2 are summarized in Table 7. Studies included raw cereals (wheat, maize, rice, barley, oat), flour, bakery products, and infant foods. DON incidence ranged from $3 \%$ in flour to $100 \%$ contamination of wheat grains, bakery products, and oats. DON contamination in infected grains is associated with the severity of FHB disease in the field. FHB control in the field during cultivation is the best way to control DON [156]. 
Table 7. Representative studies on the occurrence of trichothecene (TC) distribution $(\mu \mathrm{g} / \mathrm{kg})$ in food samples around the world during $2014-2019$.

\begin{tabular}{|c|c|c|c|c|c|c|c|c|}
\hline Country & Food Matrix & TCs & $N$ Samples & Incidence \% & Mean $\mu \mathrm{g} / \mathrm{kg}$ & Range $\mu \mathrm{g} / \mathrm{kg}$ & Detection Technique & Reference \\
\hline China & Wheat & $\mathrm{DON}$ & 38 & 100 & 106.5 & $0.5-604.0$ & LC-MS/MS & [157] \\
\hline China & Maize & DON & 44 & 65.9 & 831.0 & $5.8-9843.3$ & HPLC & {$[87]$} \\
\hline \multirow{2}{*}{ Romania } & Wheat & \multirow{2}{*}{$\mathrm{DON}$} & 31 & 26 & 748 & $110-1787$ & \multirow{2}{*}{ LC-MS/MS } & \multirow{2}{*}{ [158] } \\
\hline & Flour & & 35 & 3 & 190 & 190 & & \\
\hline Pakistan & Rice & DON & 180 & 8 & 6.99 & $<\mathrm{LOD}$ & LC-MS/MS & [159] \\
\hline Brazil & Wheat & $\mathrm{DON}$ & 48 & 100 & 2398 & $1329-3937$ & HPLC & [160] \\
\hline Italy & Wheat & DON & 293 & 97 & $\mathrm{NA}^{\mathrm{a}}$ & $56-27088$ & GC-MS & [161] \\
\hline Brazil & Wheat & DON & 53 & 47 & 641 & $243-2281$ & HPLC & [162] \\
\hline China & Wheat & $\mathrm{DON}$ & 348 & 91 & 240 & $240-1129$ & LC-MS/MS & [85] \\
\hline Iran & Wheat & $\mathrm{DON}$ & 96 & 83 & 630 & $23-1270$ & & [163] \\
\hline Finland & Wheat & $\mathrm{DON}$ & 30 & $\mathrm{NA}^{\mathrm{a}}$ & 866 & NA-5510 & LC-MS/MS & [164] \\
\hline Brazil & Wheat & DON & 58 & 91 & 360 & NA-1310 & HPLC & [165] \\
\hline \multirow{2}{*}{ Brazil } & \multirow{2}{*}{ Wheat } & \multirow{2}{*}{ DON } & \multirow{2}{*}{745} & \multirow{2}{*}{86} & 1690 & NA-8501 & \multirow{2}{*}{ HPLC } & \multirow{2}{*}{ [166] } \\
\hline & & & & & 407 & NA-2419 & & \\
\hline Brazil & Wheat & $\mathrm{DON}$ & 150 & 99 & 706 & $183-2150$ & HPLC & [167] \\
\hline Hungary & Wheat & DON & 29 & 72 & $\mathrm{NA}^{\mathrm{a}}$ & NA-1880 & ELISA & [168] \\
\hline Argentina & Wheat & DON & 84 & 100 & 1750 & NA-9480 & LC-MS/MS & [169] \\
\hline Switzerland & Wheat & $\mathrm{DON}$ & 686 & 80 & 607 & NA-10600 & LC-MS/MS & [170] \\
\hline Brazil & Wheat & $\mathrm{DON}$ & 172 & 77 & 234 & $73-2794$ & HPLC & [171] \\
\hline Poland & Wheat & DON & 92 & 83 & 140 & $10-1265$ & HPLC & [172] \\
\hline China & Wheat & DON & 181 & 82 & 500 & $33-3030$ & HPLC & [173] \\
\hline
\end{tabular}


Table 7. Cont.

\begin{tabular}{|c|c|c|c|c|c|c|c|c|}
\hline Country & Food Matrix & TCs & $N$ Samples & Incidence $\%$ & Mean $\mu \mathrm{g} / \mathrm{kg}$ & Range $\mu \mathrm{g} / \mathrm{kg}$ & Detection Technique & Reference \\
\hline \multirow{2}{*}{ Hungary } & \multirow{2}{*}{ Maize } & DON & 29 & 86 & 1872 & $225-2963$ & \multirow{2}{*}{ ELISA } & \multirow{2}{*}{ [168] } \\
\hline & & $\mathrm{T}-2$ & 29 & 55 & 69 & NA-146 & & \\
\hline \multirow{2}{*}{ Serbia } & Corn flour & \multirow{2}{*}{ DON } & 56 & 42.9 & 101 & NA-931 & \multirow{2}{*}{ HPLC } & \multirow{2}{*}{ [174] } \\
\hline & Cornflakes & & 15 & 40 & 255 & NA-878 & & \\
\hline Brazil & Barley & DON & 76 & 94 & $310-15,500$ & $1700-7500$ & LC-MS/MS & [175] \\
\hline Brazil & Bakery Products & $\mathrm{DON}$ & 36 & 100 & 591 & $60-1720$ & HPLC & [165] \\
\hline India & Infant Foods & DON & 29 & 66 & $\mathrm{NA}^{\mathrm{a}}$ & $5-228$ & ELISA & [176] \\
\hline Germany & Noodles and Pasta & DON & 40 & 97 & 387 & $60-1609$ & HPLC & [165] \\
\hline Finland & Oat & DON & 31 & 100 & $\mathrm{NA}^{\mathrm{a}}$ & 23,800 & LC-MS/MS & [164] \\
\hline UK & Oat & DON & 303 & 32 & 28 & NA-1866 & LC-MS/MS & [177] \\
\hline Finland & Oat & DON & 1672 & 79 & $\mathrm{NA}^{\mathrm{a}}$ & NA-21608 & GC-MS & [178] \\
\hline Poland & Oat & $\mathrm{DON}$ & 147 & 31 & $\mathrm{NA}^{\mathrm{a}}$ & NA-2975 & HPLC-HRMS & [179] \\
\hline Tunisia & $\begin{array}{l}\text { Cereal-based } \\
\text { products }\end{array}$ & HT-2 & 32 & 3 & 1 & $<$ LOD-209 & LC-MS/MS & [153] \\
\hline \multirow[t]{2}{*}{ Lebanon } & \multirow{2}{*}{$\begin{array}{l}\text { Wheat grains, wheat } \\
\text { flour, and bread }\end{array}$} & HT-2 & \multirow[t]{2}{*}{137} & \multirow[t]{2}{*}{0} & \multirow[t]{2}{*}{-} & \multirow[t]{2}{*}{-} & \multirow[t]{2}{*}{ LC-MS/MS } & \multirow[t]{2}{*}{ [180] } \\
\hline & & $\mathrm{T}-2$ & & & & & & \\
\hline \multirow[t]{2}{*}{ Spain } & \multirow[t]{2}{*}{$\begin{array}{l}\text { Cereal-based food, } \\
\text { beer }\end{array}$} & HT-2 & 479 & $\mathrm{NA}^{\mathrm{a}}$ & $0.047-0.214$ & $\mathrm{NA}^{\mathrm{a}}$ & \multirow{2}{*}{ GC-ECD } & [181] \\
\hline & & $\mathrm{T}-2$ & 479 & 0.006 & $0.215-0.072$ & $\mathrm{NA}^{\mathrm{a}}$ & & \\
\hline Spain & Wheat semolina & HT-2 & 15 & 33.3 & 8.9 & $6.7-15.2$ & GC-QqQ-MS/MS & [182] \\
\hline
\end{tabular}

${ }^{\mathrm{a}} \mathrm{NA}-$ not available in the publication. 


\subsection{Zearalenone}

The fungi of the Fusarium genus produce ZEN; in particular, fungal species of $F$. graminearum (Gibberella zeae), F. culmorum, F. crookwellense, F. semitectum, and F. equiseti are the major producers of ZEN, infecting cereals and food worldwide, mainly in temperate climates $[1,183]$. While contamination with ZEN is low in grains in the field, it increases in storage conditions with moisture of more than $30 \%-40 \%$ [1]. Currently, the limits for ZEN in cereals vary between countries and range from 50 to $1000 \mu \mathrm{g} / \mathrm{kg}$ [184]. A TDI for ZEN of $0.25 \mu \mathrm{g} / \mathrm{kg}$ b.w./day was established by the EFSA [40]. Moreover, maximum permissible limits for ZEN should be within the range of 100-200 $\mu \mathrm{g} / \mathrm{kg}$ in unprocessed cereals, $75 \mu \mathrm{g} / \mathrm{kg}$ for processed cereals, $20 \mu \mathrm{g} / \mathrm{kg}$ in processed cereal foods, and $50 \mu \mathrm{g} / \mathrm{kg}$ in cereal snacks according to EU legislations [185]. Risk assessments were performed on the basis of ZEN exposure data in France, Germany, Finland, China, and India.

In only a few cases, the possible ZEN intake was found to exceed the TDI, and almost all studies agreed that the majority of the population did not exceed the TDI value given by the EU [183]. ZEN is soluble in aqueous alkali, acetone, acetonitrile, benzene, methyl chloride, alcohols, and ethers, but insoluble in water [98]. The IARC classifies ZEA as a Group 3 carcinogen [49]. ZEN is a non-steroidal estrogenic mycotoxin and works by mimicking the effects of the female estrogen hormone, affecting conception, ovulation, and fetal development at concentrations above $1 \mathrm{mg} / \mathrm{kg}$ [166]. ZEN can lead to hyperestrogenism, mainly affecting reproduction. The most susceptible species to ZEN infection are prepubertal swine. Swelling of the vulva, increases in uterine size and secretions, mammary gland hyperplasia and secretion, prolonged estrus, anestrus, increased incidence of pseudopregnancy, infertility, decreased libido, and secondary complications of rectal and vaginal prolapses, stillbirths, and small litters are some of the typical clinical symptoms of hyperestrogenism [1].

Occurrence of ZEN is reported both in various developed countries like Germany [186], and Japan [187] and in developing countries like Egypt [188], Thailand [189], Iran [190] Croatia [154], and the Philippines [161]. It is worth mentioning that zearalenone is a synthetic nonsteroidal estrogen of the resorcylic acid lactone group related to mycoestrogens found in fungi in the Fusarium genus, and it is used mainly as an anabolic agent in veterinary medicine, where it can also contribute to related exposure/toxicity [191]. Table 8 presents representative studies on the occurrence of ZEN $(\mu \mathrm{g} / \mathrm{kg})$ in food samples worldwide during 2014-2019. 
Table 8. Representative studies on the occurrence of ZEN distribution $(\mu \mathrm{g} / \mathrm{kg})$ in food samples around the world during 2014-2019.

\begin{tabular}{|c|c|c|c|c|c|c|c|}
\hline Country & Food Matrix & N Samples & Incidence $\%$ & ${ }^{\text {a }}$ Mean $\mu \mathrm{g} / \mathrm{Kg}$ & ${ }^{a}$ Range $\mu \mathrm{g} / \mathrm{Kg}$ & Detection Technique & Reference \\
\hline China & Wheat & 348 & 13.2 & 8.4 & $<0.25-98.8$ & LC-MS/MS & [85] \\
\hline China & Maize & 50 & 94 & 109.1 & $0.2-3613.0$ & LC-MS/MS & [192] \\
\hline China & Maize & 44 & 13.6 & 50.8 & $40.7-1056.8$ & HPLC & [87] \\
\hline Hungary & Maize & 29 & 41 & 267 & $\mathrm{NA}^{\mathrm{a}}-565$ & ELISA & [168] \\
\hline South Korea & Infant formula & 36 & 25 & $\mathrm{NA}^{\mathrm{a}}$ & $3.3-17.6$ & UHPLC & [193] \\
\hline Serbia & Crop maize & 90 & 0 & - & - & ELISA & [137] \\
\hline Pakistan & Rice & 180 & 15 & 8.48 & $\mathrm{NA}^{\mathrm{a}}$ & LC-MS/MS & [159] \\
\hline Lebanon & Spices & 94 & 30 & 30.6 & $0.4-305.4$ & LC-MS/MS & [74] \\
\hline Brazil & Wheat flour & 39 & 2.6 & - & 26.7 & UPLC-MS/MS & [194] \\
\hline China & Peanut & 28 & 36 & $\mathrm{NA}^{\mathrm{a}}$ & $0.09-26.8$ & HPLC & [113] \\
\hline \multirow{2}{*}{ China } & Grapes & 36 & 6 & $\mathrm{NA}^{\mathrm{a}}$ & $0.29-0.36$ & \multirow{2}{*}{ UHPLC-MS/MS } & \multirow{2}{*}{ [75] } \\
\hline & Wine & 42 & 7 & $\mathrm{NA}^{\mathrm{a}}$ & $<$ LOQ to 1.85 & & \\
\hline Syria & Wheat & 40 & 25 & 13 & $4-34$ & LC-MS/MS & [112] \\
\hline Italy & Wheat & 47 & 34 & 44 & $7-230$ & HPLC-MS/MS & [112] \\
\hline Qatar & $\begin{array}{l}\text { Baby food, milk } \\
\text { based }\end{array}$ & 51 & 37 & NA & $1-\geq 5$ & HPLC & [114] \\
\hline
\end{tabular}

a NA: Not available in the Publication. 


\subsection{Emerging Fusarium Mycotoxins (Fusaproliferin, Moniliformin, Beauvericin, NX-2 Toxin, and Enniatins)}

In recent years, emerging mycotoxins became a major issue due to their high occurrence in cereals and their products [120]. In a more recent paper, emerging mycotoxins were defined as "mycotoxins, which are neither routinely determined, nor legislatively regulated; however, the evidence of their incidence is rapidly increasing" [195]. Currently, an opinion on the presence of ENNs and BEA in food and feed was reported by the EFSA without a risk assessment due to the lack of relevant toxicity data. Moreover, until now, there are no maximum levels for emerging Fusarium mycotoxins [196].

Fusaproliferin is a bicyclic sesterterpene produced by Fusarium species such as F. proliferatum F. subglutinans, and F. verticillioides [197]. FUs showed toxicity on chicken embryos and brine shrimp larvae [197].

Structurally, MON is a 1-hydroxycyclobut-1-ene-3,4 dion, a small molecule, soluble in water, which can be produced by F. verticillioides, F. begoniae, F. denticulatum, F. lactis, F. nisikadoi, F. phyllophilum, F. pseudocircinatum, F. pseudonygamai, F. ramigenum, F. tricinctum, F. acutatum, F. anthophilum, F. bulbicola, F. concentricum, F. diaminii, F. fujikuroi, F. napiforme, F. nygamai, F. proliferatum, F. pseudoanthophilum, F. sacchari, F. subglutinans, F. thapsinum, F. beomiforme, F. oxysporum, F. redolens, F. chlamydosporum, F. arthrosporiodes, F. avenaceum, and F. acuminatum [198], and recently proven to be a metabolite of Penicillium melanoconidium [197].

Structurally, BEA is cyclic hexadepsipeptide consisting of an alternating sequence of three D-a-hydroxy-iso-valeryl- and $N$-methyl-L-phenylalanyl residues [199]. BEA was first isolated from Beauveria bassiana, a fungus that causes diseases in insects [199], but it is frequently found in corn and corn-based foods and feeds infected by Fusarium spp. BEA occurs in cereal and cereal-based products not only in different European countries such as Romania [200], Spain [201], Italy [112], and Czech Republic [92], but also throughout the world in countries such as Japan [202], Tanzania, Rwanda [203], Iran [204], and Morocco [205]. BEA has antibacterial, antifungal, and insecticidal activities and causes toxic effects such as induction of apoptosis, increased concentration of cytoplasmic calcium, and DNA fragmentation in mammalian cell lines [199].

A new trichothecene mycotoxin, named NX-2, was recently characterized in rice cultures. NX-2 is similar in structure and similar in toxicity to $3-\mathrm{ADON}$, but lacks the keto group at C-8; hence, it is a type A trichothecene [206].

The Fusarium species identified as producers of ENNs are F. merismoides, F. acuminatum, F. arthrosporioides, F. avenaceum, F. compactum, F. culmorum, F. equiseti, F. kyushuense, F. langsethiae, F. lateritium, F. oxysporum, F. poae, F. sambucinum, F. scirpi, F. sporotrichioides, F. torulosum, F. tricinctum, and F. venenatum [207]. Fusarium species capable of producing ENNs can be found in different geographical areas, and the extent of seed contamination is only occasionally as high as $\mathrm{mg} / \mathrm{kg}$ [208]. ENNs contaminate not only cereal grains but also many kinds of foods including vegetable oil, beans, dried fruits, tree nuts, and coffee [196]. The ENNs most detected in foods and feed are enniatin A, (ENA), enniatin A1 (ENA1), enniatin B (ENB), and enniatin B1 (ENB1) [209]. With regard to enniatins, there is relatively little to indicate that it is of concern to humans and animals; however, it may play a role in pronouncing the impact of other Fusarium toxins (i.e., DON) by inhibiting cellular export [210].

Due to their high prevalence in feed and food, possibly at high concentrations, as well as their potential toxicity to animals and humans, research interest in emerging mycotoxins increased [199]. Table 9 presents representative studies on the occurrence of emerging Fusarium mycotoxins $(\mu \mathrm{g} / \mathrm{kg})$ in food commodities worldwide during 2014-2019. 
Table 9. Representative studies on the occurrence of emerging Fusarium mycotoxins distribution ( $\mu \mathrm{g} / \mathrm{Kg})$ in food samples around the world during $2014-2019$.

\begin{tabular}{|c|c|c|c|c|c|c|c|c|}
\hline Country & Food Matrix & $\begin{array}{c}\text { Emerging } \\
\text { Fusarium } \\
\text { mycotoxins }\end{array}$ & N Samples & ${ }^{\text {a }}$ Incidence \% & Mean $\mu \mathrm{g} / \mathrm{Kg}$ & ${ }^{b}$ Range $\mu \mathrm{g} / \mathrm{Kg}$ & Detection Technique & Reference \\
\hline Serbia & Maize & FP & 21 & 76 & - & $85.4-1121$ & LC-MS/MS & [196] \\
\hline \multirow{3}{*}{ Japan } & Corn & BEA & 44 & 34 & 3.8 & $\mathrm{NA}^{\mathrm{b}}-26.1$ & \multirow{3}{*}{ LC-MS/MS } & \multirow{3}{*}{ [202] } \\
\hline & Wheat flour & & 66 & $\mathrm{Nd}^{\mathrm{a}}$ & - & - & & \\
\hline & Wheat flour & ENB & 66 & 81.8 & 33.4 & $\mathrm{NA}^{\mathrm{b}}-237$ & & \\
\hline Italy & Wheat & BEA & 43 & 14 & 0.0004 & 0.0018-0.0051 & HPLC-MS/MS & [112] \\
\hline Syria & Wheat & BEA & 40 & 13 & 0.0002 & $0.0015-0.0017$ & HPLC-MS/MS & [112] \\
\hline Italy & Wheat & BEA & 54 & 67 & - & $0.04-5.28$ & LC-MS/MS & [211] \\
\hline Italy & Durum wheat & BEA & 108 & 94 & - & $0.03-56.40$ & LC-MS/MS & [211] \\
\hline \multirow{5}{*}{ Morocco } & \multirow{5}{*}{ Wheat } & BEA & \multirow{5}{*}{80} & 10 & 0.9 & $N^{b}{ }^{b}-16$ & \multirow{5}{*}{ LC-MS/MS } & \multirow{5}{*}{ [205] } \\
\hline & & ENA & & 14 & 6.8 & $\mathrm{NA}^{\mathrm{b}}-75$ & & \\
\hline & & ENA1 & & 18 & 13 & $\mathrm{NA}^{\mathrm{b}}-134$ & & \\
\hline & & ENB & & 61 & 57 & $\mathrm{NA}^{\mathrm{b}}-2570$ & & \\
\hline & & ENB1 & & 53 & 27 & $\mathrm{NA}^{\mathrm{b}}-345$ & & \\
\hline Serbia & Maize & ENNs & 29 & 10 & - & $0.12-0.47$ & LC-MS/MS & [212] \\
\hline Italy & Wheat & ENA & 43 & 14 & 0.0012 & $0.0031-0.0181$ & HPLC-MS/MS & [112] \\
\hline Syria & Wheat & ENA & 40 & 10 & 0.0002 & $0.0015-0.0022$ & HPLC-MS/MS & [112] \\
\hline
\end{tabular}

a Nd: Not detected. ${ }^{b}$ NA - Not available in the Publication. 


\subsection{Ergot Alkaloids}

The EA group of mycotoxins is derived from the genus Claviceps, which is a phytopathogen, with effects known from the Middle Age (ergotism, the human disease historically known as St. Anthony's Fire) [42], and it is classified as a tryptophan-derived alkaloid [213]. Fungal structures of Claviceps species are produced instead of kernels on grain ears or seeds on grass heads, with large and dark sclerotia representing the final stage of the disease, known as "ergots" [213]. Psychological and physiological effects in humans can occur by ergot poisoning, affecting blood supply to the extremities and central nervous system, while, in animal health, there are problems associated with reduced productivity, diarrhea, and internal bleeding [44,214].

In Europe, a series of EAs, such as ergocryptine, ergocristine, ergotamine, ergosine, ergometrine, ergocornine, and their corresponding epimers can be detected in the sclerotia after the contamination of Claviceps purpurea, which is the major producer of EAs [68]. C. purpurea is widespread throughout the world and infects many monocotyledonous plants, like cereal grains and forage grasses [42,215]. Main affected crops by EAs are cereals like rye, barley, wheat, millet, oats, and triticale [216]. Among cereals, rye has the highest rates of fungal contamination by $C$. purpurea as it is a cross-pollinator with large open florets [217]. As a result, ergot alkaloids appear more in rye and rye-based foods as compared to other cereals [217]. Even if ergot bodies are removed by a hand-cleaning procedure, EAs could remain in grains [214].

Ergocristine, ergosine, ergotamine, ergometrine, ergocornine, and ergocryptine are the EAs with the highest frequency of detection [214]. In the EU, no maximum permitted levels of EAs are set for feed or food, and the only available standard (EU) sets a limit of $0.5 \mathrm{~g} / \mathrm{kg}$ for the sum of ergot alkaloids in unprocessed cereals, except for maize and rice [218]. Based on toxicological studies on their vasoconstrictive effects and following an estimate of human and animal dietary exposure by the EFSA, a group TDI of $0.6 \mu \mathrm{g} / \mathrm{kg}$ b.w./day was derived [213]. The maximum permissible level of $300 \mathrm{mg}$ of ergot bodies/kg grain was set by the United States and Canada, while $0.01 \%$ is the limit in China of the total ergot alkaloid content in cereals [217]. Table 10 presents representative studies on the occurrence of EAs $(\mu \mathrm{g} / \mathrm{kg})$ in food samples worldwide during 2014-2019. 
Table 10. Representative studies on the occurrence of Ergot alkaloids distribution $(\mu \mathrm{g} / \mathrm{Kg})$ in food samples around the world during $2014-2019$.

\begin{tabular}{|c|c|c|c|c|c|c|c|}
\hline Country & Food Matrix & N Samples & $\mathrm{a}, \mathrm{b}$ Incidence $\%$ & ${ }^{b}$ Mean $\mu \mathrm{g} / \mathrm{Kg}$ & Range $\mu \mathrm{g} / \mathrm{Kg}$ & Detection Technique & Reference \\
\hline Albania & Wheat & 35 & 48.6 & 337.2 & $17.3-975.4$ & LC-MS/ MS & [215] \\
\hline Canada & Barley & 67 & 73 & 1150.50 & 2.21-29424.6 & LC-MS/ MS & [214] \\
\hline Italy & Wheat-based products & 55 & 85 & $\mathrm{NA}^{\mathrm{b}}$ & $2.5-1142.6$ & LC-MS/MS & [42] \\
\hline China & Cereal samples & 123 & $\mathrm{Nd}^{\mathrm{a}}$ & - & - & LC-MS/MS & [219] \\
\hline Canada & Cereals & 228 & $\mathrm{NA}^{\mathrm{b}}$ & $\mathrm{NA}^{\mathrm{b}}$ & $65-1140$ & LC-MS/MS & [216] \\
\hline
\end{tabular}

${ }^{a}$ Nd: Not detected. ${ }^{b}$ NA: Not available in the Publication. 


\subsection{Alternaria Toxins (Altenuene, Alternariol, Alternariol Methyl Ether, Altertoxin, Tenuazonic Acid, Tentoxin)}

The Alternaria species can be found everywhere and in many ecosystems such as plants, seeds, agricultural commodities, atmosphere, and soil [220]. They produce Alternaria toxins that contaminate foods in storage [221], with AOH, AME, TeA, ALT, ATXs, and TeA being the most important. More than 70 secondary metabolites are produced by the toxin-producing Alternaria [222], including species such as A. alternata, A. brassicae, A. dauci, A. japonica, A. solani, A. tenuissima, and A. triticina [220]. Moreover, over 30 mycotoxins were isolated belonging to different classes based on chemical structure [221]. The genus Alternaria includes saprophytic, endophytic, and pathogenic species, and it is a cosmopolitan fungal genus found in natural and anthropogenic environments [220]. Among the Alternaria species, A. alternata is the most common in harvested fruit and vegetables, and it is the most important species producing mycotoxins [222]. AOH, AME, and ALT belong to dibenzo- $\alpha$-pyrone derivatives, while ATXs belong to perylene quinone derivatives [223]. TeA belongs to tetramic acid derivatives with antibacterial and phytotoxic activities and acute toxicity for mice, chicken, and dogs, as well as hematological disorders in human [224].

According to the EFSA, among ATs, the most frequently studied are AOH, AME, and TeA [222]. Although most ATs exhibit only low acute toxicity, AOH and AME are the most toxic due to mutagenic, carcinogenic, cytotoxic, and genotoxic effects, with evidence from in vitro toxicological studies using bacterial and mammalian cells [225]. AOH is more genotoxic than AME in human carcinoma colon cells [224]. Currently, there are no regulatory limits or monitoring guidelines established for ATs in food worldwide. The risk assessment for Alternaria toxins entitled "Dietary exposure assessment to Alternaria toxins in the European population" for four of the known ATs, namely, AOH, AME, TeA, and TEN, with the highest exposure to $\mathrm{AOH}, \mathrm{AME}$, and TeA in "toddlers" and "other children", was recently published by the EFSA. The TTC approach (toxicological concern threshold) was implemented by the EFSA as there is little or no toxicity data on ATs in order to assess the levels of concern for human health. For genotoxic ATs (AOH and AME), a TTC value of $2.5 \mathrm{ng} / \mathrm{kg}$ b.w./day was set, whereas, for non-genotoxic ATs (TeA and TEN), a TTC value of $1500 \mathrm{ng} / \mathrm{kg} \mathrm{b.w./day} \mathrm{was} \mathrm{set,} \mathrm{and} \mathrm{these} \mathrm{exposure}$ estimates are unlikely to be a concern for human health [44]. A major need for the assessment of exposure of humans and animals to potential health risks is the acquisition of additional toxicological data on the contamination of food and feed with ATs [222].

Substrate composition, temperature, $\mathrm{pH}$, and $\mathrm{a}_{\mathrm{w}}$ are the most important biotic and abiotic parameters affecting the biosynthesis of mycotoxins and, thus, the biosynthesis of ATs. In particular, $\mathrm{a}_{\mathrm{w}}$ and $\mathrm{pH}$ affect most the biosynthesis of A. alternata [224]. Table 11 shows representative studies on the occurrence of ATs $(\mu \mathrm{g} / \mathrm{kg})$ in food samples worldwide during 2014-2019. 
Table 11. Representative studies on the occurrence of Alternaria toxins distribution $(\mu \mathrm{g} / \mathrm{kg}$ or $\mu \mathrm{g} / \mathrm{L})$ in food samples around the world during $2014-2019$.

\begin{tabular}{|c|c|c|c|c|c|c|c|c|}
\hline Country & Food Matrix & Alternaria Toxins & N Samples & ${ }^{\mathrm{a}}$ Incidence $\%$ & ${ }^{b}$ Mean $\mu \mathrm{g} / \mathrm{Kg}$ & Range $\mu \mathrm{g} / \mathrm{Kg}$ & Detection Technique & Reference \\
\hline \multirow{4}{*}{ China } & \multirow{4}{*}{ Dried fruits } & $\mathrm{AOH}$ & \multirow{4}{*}{220} & 2.3 & 12.0 & $3.5-27.4$ & \multirow{4}{*}{ LC-MS/ MS } & \multirow{4}{*}{ [108] } \\
\hline & & $\mathrm{TeA}$ & & 42.7 & 465.5 & $6.9-5665.3$ & & \\
\hline & & AME & & 8.2 & 3.0 & $0.2-15.0$ & & \\
\hline & & TEN & & 20.5 & 120.5 & $1.4-1032.6$ & & \\
\hline \multirow{3}{*}{ China } & \multirow{3}{*}{ Wheat } & $\mathrm{TeA}$ & 370 & 100 & 289.0 & $6.0-3330.7$ & \multirow{3}{*}{ LC-MS/ MS } & \multirow{3}{*}{ [226] } \\
\hline & & $\mathrm{AOH}$ & 370 & 47 & 12.9 & $1.3-74.4$ & & \\
\hline & & AME & 370 & 15 & 9.1 & $0.3-54.8$ & & \\
\hline \multirow{3}{*}{ Argentina } & Flour & \multirow{3}{*}{$\mathrm{TeA}$} & 23 & 61 & 7360 & LOQ-17,719 & \multirow{3}{*}{ HPLC-DAD } & \multirow{3}{*}{ [224] } \\
\hline & Wheat & & 21 & 57.1 & 19,190 & LOQ-92,000 & & \\
\hline & Bran & & 21 & 66.7 & 16,760 & LOQ-82,600 & & \\
\hline \multirow{2}{*}{ Italy } & Dried tomatoes & \multirow{2}{*}{$\mathrm{TeA}$} & 10 & 100 & 16,291 & $425-81,592$ & \multirow{2}{*}{ LC-MS/MS } & \multirow{2}{*}{ [227] } \\
\hline & Fresh tomatoes & & 8 & 100 & 1,010 & $11-4560$ & & \\
\hline \multirow{2}{*}{ Germany } & Juice samples & TeA & 88 & 62 & $\mathrm{NA}^{\mathrm{b}}$ & $1.4-19.2$ & \multirow{2}{*}{ LC-MS/MS } & \multirow{2}{*}{ [223] } \\
\hline & Red wine & AME & 11 & $\mathrm{Nd}^{\mathrm{a}}$ & - & - & & \\
\hline \multirow{4}{*}{ China } & Wheat flour & \multirow{4}{*}{$\mathrm{TeA}$} & 181 & 99.4 & 88.4 & $1.76-520$ & \multirow{4}{*}{ UPLC-MS/MS } & \multirow{4}{*}{ [228] } \\
\hline & Dried noodle & & 52 & 96.2 & 47.6 & $4.86-158$ & & \\
\hline & Bread & & 50 & 98 & 11.7 & $1.95-38.2$ & & \\
\hline & Steamed bread & & 40 & 100 & 21.2 & $6.56-46.3$ & & \\
\hline
\end{tabular}

${ }^{a}$ Nd: Not detected. ${ }^{b}$ NA: Not available in the Publication. 
The studies were conducted in dried fruits, in wheat and wheat-based products, in fresh and dried tomatoes, in juice samples, and in red wine. ATs that are the focus of most studies are AOH, AME, TEN, TeA, and ALT [223]. The occurrence of ATs is reported in various countries like Germany [223], Argentina [224], Canada [221,229], China [108], the Netherlands [230], and Italy [227]. ATs are detected in a large range of foodstuff commodities such as dried fruit [108], wheat, bran, flour [224,228-230], fresh and dried tomatoes [228], peppers [231], wine, vegetable juices, fruit juices [223], beer [232], cereal-based products such as rice and oat flake [233], sunflower seeds, and sunflower oil [222].

\subsection{Patulin}

Structurally, PAT is a heterocyclic lactone (4-hidroxi-4H-furo [3,2-c]piran-2(6H)-ona). It has a molecular weight of $154.12 \mathrm{~g} / \mathrm{mol}$ and low volatility [233,234]. In total, 60 different fungal species such as Penicillium expansum (P. leucopus), P. crustosum, P. patulum (P. urticae and P. griseofulvum), and $A$. clavatus produce PAT, whereas $P$. expansum is the most common PAT producer [233]. The strain significantly determines the amount of patulin produced. Neurotoxicity, immunotoxicity, carcinogenesis, teratogenicity, and mutagenicity are acute and chronic effects exerted by patulin on cell cultures [235]. Patulin causes immunotoxic and neurotoxic effects in animals, and there is no clear evidence that it is carcinogenic to humans [224].

The EU, US Food and Drug Administration, and Chinese legislation all set the upper limit of $50 \mu \mathrm{g} / \mathrm{L} / \mathrm{kg}$ patulin in apple and fruit juices [234]. For fruit juices, concentrated fruit juices such as reconstituted and fruit nectars, and spirit drinks, cider, and other fermented drinks derived from apples or containing apple juice, the EU established maximum levels of $50 \mu \mathrm{g} / \mathrm{kg}$. For solid apple products, including apple compote and apple puree intended for direct consumption, the EU established maximum levels of $25 \mu \mathrm{g} / \mathrm{kg}$. For apple juice and solid apple products, including apple compote and apple puree, for infants and young children and labeled and sold as such, the EU established maximum levels of $10 \mu \mathrm{g} / \mathrm{kg}$ [235]. The JECFA implemented a PMTDI of $0.4 \mathrm{mg} / \mathrm{kg}$ b.w./day for PAT [224] in 1995.

PAT is found in fruits and vegetables, especially apples and apple products in various parts of the world, and occasionally in other fruits such as pears, oranges, grapes, and their products [236-240]. If rotten fruits, especially apples, are not removed during fruit juice processing, patulin is transferred to juices [224]. PAT was initially studied as a potential antibiotic, but subsequent research showed human toxicity, including nausea, vomiting, ulceration, and hemorrhage [3]. The EU, US, and China present major problems of PAT contamination as they are the main producers of apples and apple products [234]. Table 12 presents representative studies on the occurrence of PAT $(\mu \mathrm{g} / \mathrm{kg}$ or $\mu \mathrm{g} / \mathrm{L})$ in food samples worldwide during 2014-2019. The studies were conducted in dried fruits (figs, raisins), juices (apple and mixed fruit), and jam. 
Table 12. Representative studies on the occurrence of PAT distribution ( $\mu \mathrm{g} / \mathrm{kg}$ or $\mu \mathrm{g} / \mathrm{L})$ in food samples around the world during $2014-2019$.

\begin{tabular}{|c|c|c|c|c|c|c|c|}
\hline Country & Food Matrix & N Samples & ${ }^{\mathrm{a}}$ Incidence $\%$ & ${ }^{\text {a }}$ Mean $\mu \mathrm{g} / \mathrm{kg}$ & Range $\mu \mathrm{g} / \mathrm{kg}$ & Detection Technique & Reference \\
\hline \multirow{4}{*}{ China } & Dried fig & 20 & 65.0 & - & $15.0-276.9$ & \multirow{4}{*}{ HPLC } & \multirow{4}{*}{ [240] } \\
\hline & Raisins and other dried fruits & 36 & 8.3 & - & $12.5-68.0$ & & \\
\hline & Juice & 20 & 10.0 & - & $8.0-16.8$ & & \\
\hline & Jam & 20 & 30.7 & - & $8.6-11.0$ & & \\
\hline China & Dried fruits source & 220 & 0.5 & 30.6 & 30.6 & LC-MS/ MS & [108] \\
\hline \multirow{2}{*}{ China } & Apple juice & 23 & 39.1 & 1.0 & $0.50-4.82$ & \multirow{2}{*}{ LC-MS/MS } & \multirow{2}{*}{ [241] } \\
\hline & Mix fruit juice & 20 & 20 & 0.74 & $0.50-2.46$ & & \\
\hline \multirow{2}{*}{ Qatar } & Fruit-based products & 13 & 100 & 20.8 & $1.02-61.3$ & \multirow{2}{*}{ LC-MS/MS } & \multirow{2}{*}{ [242] } \\
\hline & Apple juice & 20 & 100 & $\mathrm{NA}^{\mathrm{a}}$ & $5.27-82.21$ & & \\
\hline Tunisia & Fruit-based products & 214 & 50 & 89 & $2-889$ & HPLC & [243] \\
\hline Pakistan & Apple & 36 & 75 & $\mathrm{NA}^{\mathrm{a}}$ & $<$ LOD-630.8 & HPLC & [239] \\
\hline China & $\begin{array}{l}\text { Apple juice (including organic and } \\
\text { conventional apple juice and } \\
\text { juice concentrate) }\end{array}$ & 4 & $\mathrm{NA}^{\mathrm{a}}$ & $\mathrm{NA}^{\mathrm{a}}$ & $<$ LOD-16.8 & HPLC & [240] \\
\hline Serbia & $\begin{array}{l}\text { Apple juice (including organic and } \\
\text { conventional apple juice and } \\
\text { juice concentrate) }\end{array}$ & 73 & 74 & $\mathrm{NA}^{\mathrm{a}}$ & $<$ LOD-65.4 & HPLC & [244] \\
\hline Argentina & $\begin{array}{l}\text { Apple juice (including organic and } \\
\text { conventional apple juice and } \\
\text { juice concentrate) }\end{array}$ & 4634 & 40 & 26 & $<$ LOD-19,622 & HPLC & [245] \\
\hline Malaysia & $\begin{array}{l}\text { Apple juice (including organic and } \\
\text { conventional apple juice and } \\
\text { juice concentrate) }\end{array}$ & 13 & 8 & $\mathrm{NA}^{\mathrm{a}}$ & $<$ LOD-26.9 & HPLC & [246] \\
\hline Italy & $\begin{array}{l}\text { Products for babies (including apple } \\
\text { juice, apple sauce, and compotes) }\end{array}$ & 26 & 0 & - & - & HPLC & [247] \\
\hline
\end{tabular}

${ }^{a}$ NA: Not available in the Publication. 


\section{Mycotoxin Control Strategies: Prevention and Decontamination/Detoxification in Foods}

The reduction of mycotoxin contamination in agricultural commodities is a very important problem in many countries worldwide, which led to various preventive measures [11]. All pre-harvest strategies aim to avoid the development of toxigenic fungi and, hence, mycotoxins. However, once mycotoxins are produced, detoxification of foods should be based on post-harvest practices [248].

\subsection{Pre-Harvest Strategies}

Strategies for pre-harvest prevention include good agricultural practices (GAPs), good manufacturing practices (GMPs), appropriate environmental factors, and favorable storage practices [248]. GAPs include the implementation of a crop rotation program, use of registered insecticides, fungicides, and herbicides for control of insect damage, fungal infection, and weed eradication, proper treatment of the seed bed, soil analysis to determine the need to add fertilizers, and enhancement of genetic synthesis to suppress mycotoxin production [249,250]. Moreover, the use of biological control agents, such as antagonistic fungi, is an important pre-harvest strategy to prevent mycotoxin contamination in staple cereals, grapes, and apples [251,252]. At food processing plants, GMPs must be applied in conjunction with GAPs to act cooperatively with hazard analysis and critical control points (HACCP) [252]. Temperature and humidity exert the greatest influence on mycotoxigenic fungi for the production of mycotoxins, among the environmental factors. As it concerns favorable storage practices, temperature, moisture level, and humidity of warehouses are crucial factors for mold growth and mycotoxin production [248].

\subsection{Post-Harvest Strategies}

Decontamination/detoxification of mycotoxins from various agricultural products is a global problem, both scientific and practical. It was shown that mycotoxins can be eliminated by natural means such as thermal insulation, radiation treatment, and low-temperature plasma, chemical methods, such as oxidation, reduction, hydrolysis, alcoholysis, and absorption, and biological methods with the use of biological agents [253]. Chemical and physical detoxification methods have many limitations; they cause nutrient loss, are time-consuming and ineffective, and need expensive equipment. In comparison, biological methods proved to be more effective, more specialized, and more environmentally friendly [254].

\subsubsection{Physical Treatment}

Various practices are used to remove mycotoxins naturally. Some of them are grading, sorting, and the removal of the obviously affected parts of a lot. Moreover, drying, washing, cleaning, segregation, milling, boiling, roasting, irradiation, extrusion, microwave heating, and peeling are used as physical treatments for mycotoxin decontamination. Implementing preventive post-harvest HACCP approaches can contribute to the problem of mycotoxin contamination [68,251].

\section{Sorting}

Undoubtedly, cleaning and sorting constitute the first step of natural disinfection. Techniques such as sorting might be regarded as superior methods since they pose no risk of producing degradable products [255]. Sorting and removal of decayed and poor-quality fruits can significantly reduce patulin levels in fruit products by up to $99 \%$ [248]. Total FBs decreased in percentage between $26 \%$ and $69 \%$ in maize after purification [255]. After sorting infected maize, a decrease of $27 \%$ to $93 \%$ FB was observed. Aflatoxin infection is usually heterogeneous; thus separation of damaged nuclei can effectively reduce infection. The use of ultraviolet radiation was also applied to reduce AFs in the sorting of cereals [256]. 


\section{Processing}

Processing techniques can reduce the concentration of mycotoxins, but they cannot completely destroy them [257]. The level of mycotoxin contamination can be reduced by softening, because the fungi accumulate on the surface of the granules. A study in Kenya showed a decrease in AFs in maize by peeling. The final flour was less contaminated, while mycotoxins DON and ZEN were detected on the surface of the granules at high levels. Temperature and time can affect the mycotoxin content of the final product. Although mycotoxins are thermally stable compounds, some conventional methods of preparing food (baking, frying) at temperatures above $100{ }^{\circ} \mathrm{C}$ may reduce certain mycotoxins. The processing temperature and moisture content of the granules affect the reduction of AFs by $50 \%-80 \%$ during the extrusion process [258]. Moreover, temperatures of $150-200{ }^{\circ} \mathrm{C}$ significantly reduced AFB1, causing 79\% average reduction, being more effective at high humidity [259].

\section{Storage}

Storage conditions play an important role in controlling mycotoxins since they affect the overall growth of fungi. In particular, two main factors, temperature and high humidity, can promote both the fungal growth and the production of mycotoxins. Storage under controlled conditions, such as packaging practices, temperature control, ventilation, and appropriate air humidity, reduce the growth of fungi and the accumulation of mycotoxins [260]. Crop losses of $20 \%$ to $50 \%$ were recorded in developing countries due to inadequate storage practices [257].

\section{Radiation}

For many stored cereals, the use of natural detoxifying agents involves the use of radiation. Radiation is usually characterized as either ionizing radiation or non-ionizing radiation [258]. Radiation can reduce or eliminate pathogenic microorganisms, but it partially removes mycotoxins in foods. It can be applied on an industrial scale and is a technique that delivers energy and changes the molecular structure of food ingredients with a series of reactions [256].

Research showed that, in irradiated distilled water and fruit juices of orange, pineapple, and tomato infected with ZEA, ZEA toxicity was reduced and ZEA radiation was safe up to an irradiation of $10 \mathrm{kGy}$. A higher dose of radiation affected the quality of the fruit juices [261]. In a recent study by Luo et al. [68], after irradiation at $50 \mathrm{kGy}$ with an electron beam in naturally infected corn to degrade ZEN and OTA, decreases of $71.1 \%$ and $67.9 \%$ were recorded. In addition, reduction of AFB1 greater than $95 \%$ (at $6 \mathrm{kGy}$ ) was achieved when gamma irradiation was used for rice processing [260]. Irradiation in apple juice for 5 min caused a significant decrease in PAT (83\%) [233].

While radiation was proposed as a promising approach to mycotoxin detoxification, its effectiveness remains questionable because it can cause physical, chemical, and biological effects following potential molecular reactions [68].

\section{Cold Plasma}

Cold plasma (CP) has strong antimicrobial effects [256] and it is used in food processing to eliminate pathogens [258]. The fourth state of matter is the alternative name of plasma, mainly consisting of photons, ions, and free radicals such as reactive oxygen and nitrogen species with unique physical and chemical properties [262,263]. Cold atmospheric pressure plasma (CAPP) technology is a different technique, which is promising, low-cost, and environmentally friendly for the decontamination of mycotoxins [256,263]. Low-pressure cold plasma was used for detoxification of up to $50 \%$ of alfatoxins on the surface of nuts [264]. This technique requires cautious use as no research on the possible formation of toxic compounds was performed [265]. 
Significant reduction of AFB1 and FB1 mycotoxins of up to $66 \%$ was achieved in maize by the use of CAPP, after just $10 \mathrm{~min}$ of treatment [263]. In addition, the use of cold atmospheric plasma caused a 93\% reduction in AFs, $90 \%$ reduction in TCs, 100\% reduction in ZEA, and $93 \%$ reduction in FUs after 8 min of exposure [266]. In addition, plasma treatments of only $5 \mathrm{~s}$ caused $100 \%$ degradation of AFB1, DON, and NIV [6].

\section{Mycotoxin Binders}

Mycotoxin binders inhibit the absorption of mycotoxins as they bind to mycotoxins and do not allow their entry into the bloodstream from the gut. Various absorbent materials are activated carbon, aluminosilicates, complex non-digestible carbohydrates, and cholesterol [267]. The use of binding mycotoxins is an alternative physical technique [268] to the microbial degradation of AFs. Cleavage of the lactone ring is a potential target for microbial enzymes, and its cleavage reduces the toxicity of AFs [268]. According to research, to remove patulin from naturally infected cider, as well as to remove aflatoxin in naturally infected milk, activated carbon was used. Mycotoxin level was reduced, but more studies are needed to ensure food safety [256].

\subsubsection{Chemical Control}

\section{Bases (Ammonia, Hydrated Oxide)}

Treatment of seeds with ammonia reduces a number of mycotoxins (AFs, FBs, OTs) to undetectable levels, while the growth of mycotoxigenic fungi is inhibited. Nevertheless, treatment with bases is forbidden in the EU for food intended for human consumption. The application of a mixture of glycerol and calcium hydroxide contributed significantly to mycotoxin detoxification [248]. Sodium hydroxide and potassium hydroxide are often used in the degradation of AFB1 in contaminated oil, although these chemicals can cause secondary contamination and have harmful effects on the nutritional value of the products [269].

\section{Chitosan}

Chitosan is a linear polysaccharide, second in abundance in nature after cellulose, inhibiting fungi, bacteria, and viruses. Biocompatibility and antimicrobial properties make chitosan very interesting for the preservation of foods $[270,271]$. The combined effects of chitosan and $a_{w}$ for controlling the fungal growth and mycotoxin production of FBs and DON by the Fusarium species (F. proliferatum, F. graminearum, and F. verticillioides) on maize and wheat were reported, showing a decrease in DON and FB production in irradiated maize and wheat grains following the application of low-molecular-weight chitosan with deacetylation above $70 \%$, and a dose of $0.5 \mathrm{mg} / \mathrm{g}$ [271]. In addition, the application of $1 \%$ chitosan enriched with $1 \%$ lemon essential oils in figs reduced the from marine brown algae Ascophyllum nodosum reduced the levels of DON in wheat grains [272].

\section{Ozone Treatment}

The use of ozone $\left(\mathrm{O}_{3}\right)$ in the degradation of several mycotoxins was reported in many papers [273-278]. Ozonation is an easy technology, which does not leave harmful residues after application. Ozone is used to disinfect cereals, vegetables, and fruits, or to detoxify mycotoxins [278].

Ozone gas was reported by Agriopoulou et al. [279] to be particularly successful in the degradation of aflatoxins, mainly AFB1 and AFG1, since there is a C8-C9 double bond in their structures. Specifically, AFG1 proved to be the most sensitive. Ozone treatment under optimum conditions $\left(55 \mathrm{~g} \mathrm{O}_{3} \cdot \mathrm{h}^{-1}\right.$ for $6 \mathrm{~h}$ ) showed a significant decrease in DON (29\%-32\%) and its modified form DON-3-glucoside (DON-3-Glc) (44\%). Moreover, significant microbial decline was observed in durum wheat, leaving chemical and rheological properties of semolina and pasta from ozonated wheat unaffected [273]. 
DON was transformed into 10 ozonized products $\left(\mathrm{C}_{15} \mathrm{H}_{18} \mathrm{O}_{7}, \mathrm{C}_{15} \mathrm{H}_{18} \mathrm{O}_{9}, \mathrm{C}_{15} \mathrm{H}_{22} \mathrm{O}_{9}, \mathrm{C}_{15} \mathrm{H}_{20} \mathrm{O}_{10}\right.$, $\mathrm{C}_{15} \mathrm{H}_{18} \mathrm{O}_{8}, \mathrm{C}_{15} \mathrm{H}_{20} \mathrm{O}_{9}, \mathrm{C}_{14} \mathrm{H}_{18} \mathrm{O}_{7}, \mathrm{C}_{14} \mathrm{H}_{16} \mathrm{O}_{6}, \mathrm{C}_{15} \mathrm{H}_{20} \mathrm{O}_{7}$, and $\left.\mathrm{C}_{15} \mathrm{H}_{20} \mathrm{O}_{10}\right)$ after treatment with gaseous ozone [280]. DON degradation rate was positively correlated with ozone concentration and treatment time. Specifically, the rate of degradation of DON in solution reached $54.2 \%$, for a treatment time of $30 \mathrm{~s}$ and an ozone concentration of $1 \mathrm{mg} \cdot \mathrm{L}^{-1}$. DON degradation was significantly influenced by the moisture content of the granules. The degradation rate of DON was $57.3 \%$ when ozone concentrations of $60 \mathrm{mg} \cdot \mathrm{L}^{-1}$ were applied for $12 \mathrm{~h}$ in wheat with a moisture content of $17.0 \%$ [278].

According to research by $\mathrm{Li}$ et al. [281], fresh noodles made from ozone-treated wheat flour retained more in relation to microbial growth.

\subsubsection{Biological Control}

In the last 20 years, many researches from groups with different backgrounds and research experience made great achievements in the search for biological agents for mycotoxin detoxification [282]. The use of microorganisms such as bacteria, yeast, and fungi in the degradation of mycotoxins in food and feed is widely reported [21,254,283]. Detoxification/degradation of mycotoxins by biological means offers an alternative approach to the control of mycotoxins, since it can lead to the production of fewer or even no toxic intermediates and end products. The use of pure microbial strains greatly contributed to the disinfection of mycotoxins in vitro. Moreover, the effectiveness of fermentation in reducing and eliminating mycotoxins was also demonstrated [251].

\section{Bacteria}

Certain bacteria have the ability to bind mycotoxins in foods or liquids [21]. The only bacterium among the more than 1000 tested for possible degradation of AFs capable of irreversibly removing aflatoxin from solutions was Flavobacterium aurantiacum B-184. Detoxification of AFB1 through Enterococcus faecium is accomplished by binding to the cell-wall elements of the bacterium. Peptidoglycans and polysaccharides of bacterial cell walls were shown to be responsible for the binding of mycotoxins with the help of microorganisms [284].

Moreover, bacterial detoxification of mycotoxin DON evolved due to research efforts and advances. Aerobic oxidation and partitioning of this mycotoxin into C 3 carbon carried by multiple species of Devosia provides solutions aimed at reducing DON contamination [282].

Lactic acid bacteria (Lactobacillus (L.) casei and Lactobacillus reuteri) proved effective in binding to AFs in aqueous solutions. In other in vitro tests, Lactobacillus amylovorus and Lactobacillus rhamnosus presented a binding efficiency of up to $60 \%$ AFB1, showing their potential to bind selected dietary contaminants [7]. Also, reductions $98 \%$ FB1 and $84 \%$ T-2 were demonstrated during the fermentation of whole-grain sorghum with Lactobacillus fermentum [285].

Yeast

The application of biological control agents (BCAs) is a promising strategy for the treatment of mycotoxin infection. The use of competing yeasts is of particular interest, since yeasts produce antimicrobial compounds with beneficial impacts on humans and animals; on the other hand they can develop rapidly on many substrates in bioreactors. In addition, unlike many filamentous fungi or bacterial antagonists, yeasts do not produce allergens or other secondary metabolites [286,287]. Saccharomyces cerevisiae is a probiotic yeast which can significantly degrade DON and reduce the rate of lactate dehydrogenase (LDH) release in DON-stimulated cells [288].

Moreover, low concentrations of mycotoxins AFB1 and OTA in chicken diets can be reduced with the addition S. cerevisiae yeast cell walls [289]. In addition, the effectiveness of reducing mycotoxin patulin by $S$. cerevisiae in fermented foods by increasing fermentation time and temperature was investigated. Yeast cells are capable of removing PAT via physical adsorption. In fact, the O-N/N-H protein and polysaccharide bonds of cell walls interact with PAT [290] Kluyveromyces marxianus were used to bind mycotoxins AFB1, OTA, or ZEA. The results showed that mycotoxins can bind to the cell 
membrane, especially to C. utilis [291]. In another study, the yeast Yarrowia lipolytica decreased the concentration of OTA to about half of the initial level introduced into the culture [241].

In addition, a yeast strain of Rhodotorula mucilaginosa (R. mucilaginosa JM19) was used to degrade PAT, and analysis was performed by HPLC-UV. The results showed that the degradation product of PAT was dexipitulic acid. The temperature, cell density, and initial concentration of PAT contributed greatly to the degradation of PAT through $R$. mucilaginosa JM19. After $21 \mathrm{~h}$ at $35^{\circ} \mathrm{C}$ and when the density of yeast cells was above $1 \times 10^{8}$ cells/L, a $90 \%$ decrease in PAT was observed. At an initial PAT concentration of $100 \mu \mathrm{g} / \mathrm{mL}$, R. mucilaginosa JM19 was shown to be capable of causing more than $50 \%$ degradation, indicating its usefulness in the degradation of PAT in foods and raw materials [292].

\section{Food Fermentation}

The fermentation of foods improves their quality while granting them particularly desirable properties for consumers. Fermentation is a fairly inexpensive mycotoxin disinfection approach that can be used both to improve the ingredients in foods and to reduce and even eliminate mycotoxins. Fermentation can be an alternative and desirable technique to reduce mycotoxins compared to costly and impractical techniques. The nature of metabolites and the toxicity of products formed after fermentation should be carefully documented in order to produce safe foods [251].

Fungi

The use of non-toxic strains of A. flavus and A. parasiticus on maize, cotton, pistachio, and peanuts yielded remarkable success in reducing aflatoxin contamination. Regarding the fungi and their detoxification, it was reported that fungi capable of producing aflatoxins could also break them down. This is because these fungi are often able to degrade and possibly convert and use degradation products as a source of energy under starvation conditions [7]. Fungi such as Aspergillus, Rhizopus, Trichoderma, Clonostachys, and Penicillium spp. show efficient abilities in the detoxification of mycotoxins [250]. In both west and east Africa, the biocontrol of AFs in maize with non-toxigenic microbial strains is based on competition. Specifically, large amounts of non-toxic inoculants of A. flavus and A. parasiticus enter the soil around the crops and compete with toxigenic strains [252].

\subsubsection{Enzymatic Detoxification}

The enzymatic detoxification of mycotoxins combines the characteristics of chemical and biological processing. It has high performance and specialization, with application under mild conditions, and it does not cause toxicity to organisms. In addition, enzymes as catalysts are involved in non-stoichiometric ratios of mycotoxins [253]. Some Aspergillus species can produce an enzyme that is naturally capable of detoxifying fumonisins, including those produced by Fusarium [293]. The activity of enzymes such as $\beta-1,3$-glucanase and chitinase against pathogens may vary depending on the characteristics of the microorganism. The delay and decrease in growth of fruit spoilage fungi are affected by the application of $\beta$-1,3-glucanases and chitinases [294]. Inhibition of Penicillium simplicissimum, A. Niger complex, Penicillium nalgiovense, and A. flavus growth on salami surface samples was induced by spraying $\beta$-glucanase at $50 \%$ and chitinase at $50 \%$ and $40 \%$ concentrations. Therefore, $\beta$-glucanase and chitinase may be a safe alternative for the fermented sausage industry to control fungal spoilage [294]. Moreover, microbial manganese peroxide, oxidase enzymes, catalase, and laccase enzymes were used for the enzymatic detoxification of AFB1 [252,258]. However, enzymes have an unexplored profile when detoxifying food contaminants due to their favorable toxicology and specialization. In the EU, no enzyme is approved for the removal of mycotoxin contamination from foodstuffs [258]. 


\subsubsection{Novel Detoxification Strategies}

Nanoparticles

Many papers proposed the removal of mycotoxins using the promising adsorbents of nanoparticles. Magnetic carbon nanocomposites were used for AFB1 detoxification, chitosan-coated $\mathrm{Fe}_{3} \mathrm{O}_{4}$ nanoparticles were reported for PAT decontamination, and silver nanoparticles were reported for degradation of Fusarium spp. and their main associated mycotoxins [248,295]. According to a recent study, a new photocatalyst nanoparticle $\mathrm{UCNP}_{\mathrm{TiO}}$ (upconversion nanoparticle) was synthesized and used to degrade DON. The results showed a decrease of DON in cereal products below the permissible limits $(1 \mathrm{ppm})$ after $90 \mathrm{~min}$ and total degradation after $120 \mathrm{~min}$ of illumination. The $\mathrm{UCNP}_{\mathrm{T}} \mathrm{TiO}_{2}$ composite material was efficient and green, and the degradation products were only slightly toxic or even non-toxic. Therefore, this degradation technology can be used for mycotoxin detoxification [296]. González-Jartín et al. [297] reported elimination of up to 87\% of mycotoxins from nanocomposites composed of mixtures of activated carbon, bentonite, and aluminum oxide.

\section{Plant Extracts}

Different essential oils (EOs) and their main bioactive compounds were used for the antifungal and antimycotoxigenic properties [298-300], and they were demonstrated to inhibit the production of some mycotoxins [273]. The use of botanicals is usually preferable in the removal of toxigenic fungi and mycotoxins compared to chemical treatments because they are considered safe to humans and environmentally friendly. Several researchers reported that the oil of clove and its major ingredient, eugenol, as well as the turmeric essential oil, inhibit Aspergillus growth and AFB1 production. The growth of A. flavus and P. citrinum and their toxins were inhibited by the application of whole clove in culture media and rice grains [248,301].

A recent scientific study demonstrated the effect of the Spanish paprika smoker "Pimentón de la Vera" on the development of A. parasiticus and P. nordicum and the production of AFB1, AFG1, and OTA. The addition $2 \%-3 \%$ Spanish paprika smoker in meat products such as fillets or sausage preparations helped minimize the development and production of mycotoxins AF and OTA [302]. Moreover, capsaicin, a natural compound, inhibited OTA production in grapes by Aspergillus section Nigri strains from $28.9 \%$ to $78.1 \%$, and by A. carbonarius of $61.5 \%$ [303].

\section{Conclusions}

Mycotoxins are among the most prominent and dangerous toxins associated with food safety. They attract worldwide attention because they are important contaminants with a multitude of effects on both human and animal health, causing significant economic problems throughout the agri-food chain. High-quality and safe foods can emerge if HACCP is implemented across the food chain from farm to fork and at all stages of food handling, providing global food security. Prevention is an important strategy in the fight against mycotoxins and should be applied in the pre-harvest stages, in raw materials and processed foods. Detoxification methods can also be applied without affecting the organoleptic characteristics of the foods. Finally, continuous monitoring of mycotoxins in food products can prevent significant problems in the marketing, distribution, and consumption of foods.

Author Contributions: Investigation, S.A.; resources, S.A., E.S., and T.V.; writing—original draft preparation, S.A. and E.S.; writing-review and editing, S.A., E.S., and T.V.; supervision, T.V. All authors have read and agreed to the published version of the manuscript.

Funding: This research received no external funding.

Conflicts of Interest: The authors declare no conflicts of interest. 


\section{References}

1. Tola, M.; Kebede, B. Occurrence, importance and control of mycotoxins: A review. Cogent Food Agric. 2016, 2, 1-12. [CrossRef]

2. Misihairabgwi, J.M.; Ezekiel, C.N.; Sulyok, M.; Shephard, G.S.; Krska, R. Mycotoxin contamination of foods in Southern Africa: A 10-year review (2007-2016). Crit. Rev. Food Sci. Nutr. 2019, 59, 43-58. [CrossRef] [PubMed]

3. Alshannaq, A.; Yu, J.H. Occurrence, toxicity, and analysis of major mycotoxins in food. Int. J. Environ. Res. Public Health 2017, 14, 632. [CrossRef]

4. Mousavi Khaneghah, A.; Fakhri, Y.; Gahruie, H.H.; Niakousari, M.; Sant'Ana, A.S. Mycotoxins in cereal-based products during 24 years (1983-2017): A global systematic review. Trends Food Sci. Technol. 2019, 91, 95-105. [CrossRef]

5. Bennett, J.W. Mycotoxins, mycotoxicoses, mycotoxicology and Mycopathologia. Mycopathologia 1987, 100, 3-5. [CrossRef]

6. Pittet, A.C. Natural occurrence of mycotoxins in foods and feeds: An update review. Rev. Med. Vet. 1998, 6, 479-492.

7. Kagot, V.; Okoth, S.; De Boevre, M.; De Saeger, S. Biocontrol of aspergillus and fusarium mycotoxins in Africa: Benefits and limitations. Toxins 2019, 11, 109. [CrossRef]

8. Alassane-Kpembi, I.; Schatzmayr, G.; Taranu, I.; Marin, D.; Puel, O.; Oswald, I.P. Mycotoxins co-contamination: Methodological aspects and biological relevance of combined toxicity studies. Crit. Rev. Food Sci. Nutr. 2017, 57, 3489-3507. [CrossRef]

9. Winter, G.; Pereg, L. A review on the relation between soil and mycotoxins: Effect of aflatoxin on field, food and finance. Eur. J. Soil Sci. 2019, 70, 882-897. [CrossRef]

10. Zain, M.E. Impact of mycotoxins on humans and animals. J. Saudi Chem. Soc. 2011, 15, 129-144. [CrossRef]

11. Ayofemi Olalekan Adeyeye, S. Aflatoxigenic fungi and mycotoxins in food: A review. Crit. Rev. Food Sci. Nutr. 2019, 59, 1-13. [CrossRef] [PubMed]

12. Aldars-garcía, L.; Berman, M.; Ortiz, J.; Ramos, A.J.; Marín, S. Probability models for growth and aflatoxin B1 production as affected by intraspecies variability in Aspergillus flavus. Food Microbiol. 2018, 72, 166-175. [CrossRef] [PubMed]

13. Lacey, J. Natural occurrence of mycotoxins in growing and conserved forage crops. In Mycotoxins and Animal Foods; Smith, J.E., Henderson, R.E., Eds.; CRC Press: Boca Raton, FL, USA, 1991; pp. 363-397.

14. Rodrigues, P.; Venâncio, A.; Lima, N. Mycobiota and mycotoxins of almonds and chestnuts with special reference to aflatoxins. Food Res. Int. 2012, 48, 76-90. [CrossRef]

15. Fountain, J.C.; Khera, P.; Yang, L.; Nayak, S.N.; Scully, B.T.; Lee, R.D.; Chen, Z.Y.; Kemerait, R.C.; Varshney, R.K.; Guo, B. Resistance to Aspergillus flavus in maize and peanut: Molecular biology, breeding, environmental stress, and future perspectives. Crop J. 2015, 3, 229-237. [CrossRef]

16. Welke, J.E. Fungal and mycotoxin problems in grape juice and wine industries. Curr. Opin. Food Sci. 2019, 29, 7-13. [CrossRef]

17. European Food Safety Authority. Deoxynivalenol in food and feed: Occurrence and exposure. EFSA J. 2013, 11, 3379.

18. Varzakas, T. Quality and safety aspects of cereals (Wheat) and their products. Crit. Rev. Food Sci. Nutr. 2016, 56, 2495-2510. [CrossRef]

19. Marin, S.; Ramos, A.J.; Cano-Sancho, G.; Sanchis, V. Mycotoxins: Occurrence, toxicology, and exposure assessment. Food Chem. Toxicol. 2013, 60, 218-237. [CrossRef]

20. Ostry, V.; Malir, F.; Toman, J.; Grosse, Y. Mycotoxins as human carcinogens-The IARC Monographs classification. Mycotoxin Res. 2017, 33, 65-73. [CrossRef]

21. Ben Taheur, F.; Kouidhi, B.; Al Qurashi, Y.M.A.; Ben Salah-Abbès, J.; Chaieb, K. Review: Biotechnology of mycotoxins detoxification using microorganisms and enzymes. Toxicon 2019, 160, 12-22. [CrossRef]

22. Kumar, P.; Mahato, D.K.; Kamle, M.; Mohanta, T.K.; Kang, S.G. Aflatoxins: A global concern for food safety, human health and their management. Front. Microbiol. 2017, 7, 2170. [CrossRef] [PubMed]

23. RASFF (Rapid Alert System for Food and Feed). Available online: https:/ec.europa.eu/food/sites/food/files/ safety/docs/rasff_annual_report_2009_en.pdf (accessed on 19 October 2019). 
24. RASFF (Rapid Alert System for Food and Feed). Available online: https:/ec.europa.eu/food/sites/food/files/ safety/docs/rasff_annual_report_2010_en.pdf (accessed on 19 October 2019).

25. RASFF (Rapid Alert System for Food and Feed). Available online: https://ec.europa.eu/food/sites/food/files/ safety/docs/rasff_annual_report_2011_en.pdf (accessed on 19 October 2019).

26. RASFF (Rapid Alert System for Food and Feed). Available online: https://ec.europa.eu/food/sites/food/files/ safety/docs/rasff_annual_report_2012_en.pdf (accessed on 19 October 2019).

27. RASFF (Rapid Alert System for Food and Feed). Available online: https://ec.europa.eu/food/sites/food/files/ safety/docs/rasff_annual_report_2013.pdf (accessed on 19 October 2019).

28. RASFF (Rapid Alert System for Food and Feed). Available online: https://ec.europa.eu/food/sites/food/files/ safety/docs/rasff_annual_report_2014.pdf (accessed on 19 October 2019).

29. RASFF (Rapid Alert System for Food and Feed). Available online: https://ec.europa.eu/food/sites/food/files/ safety/docs/rasff_annual_report_2015.pdf (accessed on 19 October 2019).

30. RASFF (Rapid Alert System for Food and Feed). Available online: https:/ec.europa.eu/food/sites/food/files/ safety/docs/rasff_annual_report_2016.pdf (accessed on 19 October 2019).

31. RASFF (Rapid Alert System for Food and Feed). Available online: https://ec.europa.eu/food/sites/food/files/ safety/docs/rasff_annual_report_2017.pdf (accessed on 19 October 2019).

32. RASFF (Rapid Alert System for Food and Feed). Available online: https://ec.europa.eu/food/sites/food/files/ safety/docs/rasff_annual_report_2018.pdf (accessed on 19 October 2019).

33. Lee, H.J.; Ryu, D. Worldwide Occurrence of Mycotoxins in Cereals and Cereal-Derived Food Products: Public Health Perspectives of Their Co-occurrence. J. Agric. Food Chem. 2017, 65, 7034-7051. [CrossRef] [PubMed]

34. Al-Jaal, B.A.; Jaganjac, M.; Barcaru, A.; Horvatovich, P.; Latiff, A. Aflatoxin, fumonisin, ochratoxin, zearalenone and deoxynivalenol biomarkers in human biological fluids: A systematic literature review, 2001-2018. Food Chem. Toxicol. 2019, 129, 211-228. [CrossRef] [PubMed]

35. Temba, B.A.; Fletcher, M.T.; Fox, G.P.; Harvey, J.; Okoth, S.A.; Sultanbawa, Y. Curcumin-based photosensitization inactivates Aspergillus flavus and reduces aflatoxin B1 in maize kernels. Food Microbiol. 2019, 82, 82-88. [CrossRef]

36. WHO (World Health Organization). New IARC report urges action against widespread mycotoxin contamination in developing countries. IARC WHO Press Release 2016, 9, 2015-2016.

37. European Commission. Commission Regulation (EC) No. 1881/2006 of 19 December 2006. Off. J. Eur. Union 2006, 364, 5 .

38. European Commission. Commission Regulation (EC) No 1126/2007, on setting maximum levels for certain contaminants in foodstuffs as regards Fusarium toxins in maize and maize products. Off. J. Eur. Union 2007, 14-17.

39. Piacentini, K.C.; Ferranti, L.S.; Pinheiro, M.; Bertozzi, B.G.; Rocha, L.O. Mycotoxin contamination in cereal-based baby foods. Curr. Opin. Food Sci. 2019, 30, 73-78. [CrossRef]

40. Ünüsan, N. Systematic review of mycotoxins in food and feeds in Turkey. Food Control 2019, 97, 1-14. [CrossRef]

41. European Commission. Commission Recommendation No 2013/165/EU of 27 March 2013 on the presence of T-2 and HT-2 toxin in cereals and cereal products. Off. J. Eur. Union 2013, 91, 12-15.

42. Debegnach, F.; Patriarca, S.; Brera, C.; Gregori, E.; Sonego, E.; Moracci, G.; De Santis, B. Ergot Alkaloids in Wheat and Rye Derived Products in Italy. Foods 2019, 8, 8050150. [CrossRef] [PubMed]

43. European Food Safety Authority; Arcella, D.; Eskola, M.; Gomez Ruiz, J.Á. Dietary exposure assessment to Alternaria toxins in the European population European. EFSA J. 2016, 14, 4654.

44. Adeyeye, S.A.O. Fungal mycotoxins in foods: A review. Cogent Food Agric. 2016, 2, 1-11. [CrossRef]

45. Xue, Z.; Zhang, Y.; Yu, W.; Zhang, J.; Wang, J.; Wan, F.; Kim, Y.; Liu, Y.; Kou, X. Recent advances in aflatoxin B1 detection based on nanotechnology and nanomaterials-A review. Anal. Chim. Acta. 2019, 1069, 1-27. [CrossRef]

46. Abbas, H.K.; Wilkinson, J.R.; Zablotowicz, R.M.; Accinelli, C.; Abel, C.A.; Bruns, H.A.; Weaver, M.A. Ecology of Aspergillus flavus, regulation of aflatoxin production, and management strategies to reduce aflatoxin contamination of corn. Toxin Rev. 2009, 28, 142-153. [CrossRef]

47. Reiter, E.; Zentek, J.; Razzazi, E. Review on sample preparation strategies and methods used for the analysis of aflatoxins in food and feed. Mol. Nutr. Food Res. 2009, 53, 508-524. [CrossRef] [PubMed] 
48. Varga, J.; Frisvad, J.C.; Ramson, R.A. Two new aflatoxin producing species, and an overview of Aspergillus section Flavi. Stud. Mycol. 2011, 69, 57-80. [CrossRef] [PubMed]

49. IARC (International Agency for Research on Cancer). Some naturally occurring substances: Food items and constituents, heterocyclic aromatic amines and mycotoxins. In IARC Monographs on the Evaluation of Carcinogenic Rirsks to Humans; World Health Organization: Lyon, France, 1993; Volume 56, pp. 1-609.

50. Hernández-Martínez, R.; Navarro-Blasco, I. Aflatoxin levels and exposure assessment of Spanish infant cereals. Food Addit. Contam. Part B Surveill. 2010, 3, 275-288. [CrossRef]

51. Zinedine, A.; Mañes, J. Occurrence and legislation of mycotoxins in food and feed from Morocco. Food Control 2009, 20, 334-344. [CrossRef]

52. Pietri, A.; Bertuzzi, T.; Agosti, B.; Donadini, G. Transfer of aflatoxin B1 and fumonisin B1 from naturally contaminated raw materials to beer during an industrial brewing process. Food Addit. Contam. Part A Chem. Anal. Control Expo. Risk Assess. 2010, 27, 1431-1439. [CrossRef]

53. Udovicki, B.; Audenaert, K.; De Saeger, S.; Rajkovic, A. Overview on the mycotoxins incidence in Serbia in the period 2004-2016. Toxins 2018, 10, 279. [CrossRef] [PubMed]

54. Assaf, J.C.; Nahle, S.; Chokr, A.; Louka, N.; Atoui, A.; André El Khoury, A. Assorted Methods for Decontamination of Aflatoxin M1 in Milk Using Microbial Adsorbents. Toxins 2019, 11, 11060304. [CrossRef] [PubMed]

55. Karunarathna, N.B.; Fernando, C.J.; Munasinghe, D.M.S.; Fernando, R. Occurrence of aflatoxins in edible vegetable oils in Sri Lanka. Food Control 2019, 101, 97-103. [CrossRef]

56. Blankson, G.K.; Mills-Robertson, F.C.; Ofosu, I.W. Survey of occurrence levels of Aflatoxins in selected locally processed cereal-based foods for human consumption from Ghana. Food Control 2019, 95, 170-175. [CrossRef]

57. Quevedo-Garza, P.A.; Amador-Espejo, G.G.; Cantú-Martínez, P.C.; Trujillo-Mesa, J.A. Aflatoxin M1 occurrence in fluid milk commercialized in Monterrey, Mexico. J. Food Saf. 2018, 38, 1-4. [CrossRef]

58. Kebede, H.; Abbas, H.K.; Fisher, D.K.; Bellaloui, N. Relationship between aflatoxin contamination and physiological responses of corn plants under drought and heat stress. Toxins 2012, 4, 1385-1403. [CrossRef]

59. Caballero, B.; Trugo, L.C.; Finglas, P.M. Encyclopedia of Food Sciences and Nutrition, 2nd ed.; Academic Press: Cambridge, MA, USA, 2003; pp. 66-72.

60. Strosnider, H.; Azziz-Baumgartner, E.; Banziger, M.; Bhat, R.V.; Breiman, R.; Brune, M.-N.; DeCock, K.; Dilley, A.; Groopman, J.; Hell, K.; et al. Workgroup report: Public health strategies for reducing aflatoxin exposure in developing countries. Environ. Health Perspect. 2006, 114, 1898-1903. [CrossRef]

61. Kabak, B.; Dobson, A.D.W.; Var, I. Strategies to prevent mycotoxin contamination of food and animal feed: A review. Crit. Rev. Food Sci. Nutr. 2006, 46, 593-619. [CrossRef]

62. Gross-Steinmeyer, K.; Eaton, D.L. Dietary modulation of the biotransformation and genotoxicity of aflatoxin B1. Toxicology 2012, 299, 69-79. [CrossRef]

63. Jaimez, J.; Fente, C.A.; Vazquez, B.I.; Franco, C.M.; Cepeda, A.; Mahuzier, G.; Prognon, P. Application of the assay of aflatoxins by liquid chromatography with fluorescence detection in food analysis. J. Chromatogr. A 2000, 882, 1-10. [CrossRef]

64. Wild, C.P.; Gong, Y.Y. Mycotoxins and human disease: A largely ignored global health issue. Carcinogenesis 2009, 31, 71-82. [CrossRef]

65. Okioma, M.N. 2004 and 2005 Afalatoxin tragedies in Kenya-A case study. In Mycotoxins, Detection Methods, Management, Puplic Health and Agricultural, Trade; Leslie, J.F., Bandyopadhyay, R., Visconti, A., Eds.; Cromwell Press: London, UK, 2008; pp. 127-133.

66. Camiletti, B.X.; Torrico, A.K.; Fernanda Maurino, M.; Cristos, D.; Magnoli, C.; Lucini, E.I.; Pecci, M.D.L.P.G. Fungal screening and aflatoxin production by Aspergillus section Flavi isolated from pre-harvest maize ears grown in two Argentine regions. Crop Prot. 2017, 92, 41-48. [CrossRef]

67. Taniwaki, M.H.; Pitt, J.I.; Copetti, M.V.; Teixeira, A.A.; Iamanaka, B.T. Understanding Mycotoxin Contamination Across the Food Chain in Brazil: Challenges and Opportunities. Toxins 2019, 11, 11070411. [CrossRef]

68. Shi, H.; Li, S.; Bai, Y.; Prates, L.L.; Lei, Y.; Yu, P. Mycotoxin contamination of food and feed in China: Occurrence, detection techniques, toxicological effects and advances in mitigation technologies. Food Control 2018, 91, 202-215. [CrossRef] 
69. Battilani, P.; Toscano, P.; Van Der Fels-Klerx, H.J.; Moretti, A.; Camardo Leggieri, M.; Brera, C.; Rortais, A.; Goumperis, T.; Robinson, T. Aflatoxin B1 contamination in maize in Europe increases due to climate change. Sci. Rep. 2016, 6, 1-7. [CrossRef]

70. Assunção, R.; Martins, C.; Viegas, S.; Viegas, C.; Jakobsen, L.S.; Pires, S.; Alvito, P. Climate change and the health impact of aflatoxins exposure in Portugal-an overview. Food Addit. Contam. Part A Chem. Anal. Control Expo. Risk Assess. 2018, 35, 1610-1621. [CrossRef]

71. Arroyo-Manzanares, N.; Rdríguez-Estévez, V.; Arenas-Fernández, P.; García-Campaña, A.M.; Gámiz-Gracia, L. Occurrence of Mycotoxins in Swine Feeding from Spain. Toxins 2019, 11, 342. [CrossRef]

72. Mohammed, S.; Munissi, J.J.E.; Nyandoro, S.S. Aflatoxins in sunflower seeds and unrefined sunflower oils from Singida, Tanzania. Food Addit. Contam. Part B Surveill. 2018, 11, 161-166. [CrossRef]

73. Kluczkovski, A.M. Fungal and mycotoxin problems in the nut industry. Curr. Opin. Food Sci. 2019, $29,56-63$. [CrossRef]

74. El Darra, N.; Gambacorta, L.; Solfrizzo, M. Multimycotoxins occurrence in spices and herbs commercialized in Lebanon. Food Control 2019, 95, 63-70. [CrossRef]

75. Zhang, B.; Chen, X.; Han, S.Y.; Li, M.; Ma, T.-Z.; Sheng, W.-J.; Zhu, X. Simultaneous analysis of 20 mycotoxins in grapes and wines from Hexi Corridor region (China): Based on a QuEChERS-UHPLC-MS/MS method. Molecules 2018, 23, 22981926. [CrossRef]

76. Silva, J.J.; Iamanaka, B.T.; Fungaro, M.H.P.; Taniwaki, M.H. Aflatoxins in sugarcane production chain: What could be the source? Curr. Opin. Food Sci. 2019, 29, 94-98. [CrossRef]

77. Abdallah, M.F.; Krska, R.; Sulyok, M. Occurrence of Ochratoxins, Fumonisin B2, Aflatoxins (B1 and B2), and Other Secondary Fungal Metabolites in Dried Date Palm Fruits from Egypt: A Mini-Survey. J. Food Sci. 2018, 83, 559-564. [CrossRef]

78. Akbar, N.; Nasir, M.; Naeem, N.; Ahmad, M.-U.-D.; Iqbal, S.; Rashid, A.; Imran, M.; Gondal, T.A.; Atif, M.; Salehi, B.; et al. Occurrence and Seasonal Variations of Aflatoxin M1 in Milk from Punjab, Pakistan. Toxins 2019, 11, 11100574. [CrossRef]

79. Fouad, A.M.; Ruan, D.; El Senouse, H.A.K.; Chen, W.; Jiang, S.; Zheng, C. Harmful effects and control strategies of aflatoxin B1 produced by aspergillus flavus and aspergillus parasiticus strains on poultry: Review. Toxins 2019, 11, 176. [CrossRef]

80. Perrone, G.; Rodriguez, A.; Magistà, D.; Magan, N. Insights into existing and future fungal and mycotoxin contamination of cured meats. Curr. Opin. Food Sci. 2019, 29, 20-27. [CrossRef]

81. Khanian, M.; Karimi-Torshizi, M.A.; Allameh, A. Alleviation of aflatoxin-related oxidative damage to liver and improvement of growth performance in broiler chickens consumed Lactobacillus plantarum 299v for entire growth period. Toxicon 2019, 158, 57-62. [CrossRef]

82. Guo, L.Y.; Zheng, N.; Zhang, Y.D.; Du, R.H.; Zheng, B.Q.; Wang, J.Q. A survey of seasonal variations of aflatoxin M1 in raw milk in Tangshan region of China during 2012-2014. Food Control 2016, 69, 30-35. [CrossRef]

83. Anthony, M.H.; Ojochenemi, A.D.; Mulunda, M.; Oriyomi, S.T.; Jideofor, N.F.; Tunde, O.; Seun, E.O.; Umuhani, Y.O.; Robertson, O.B.; Isah, A.; et al. Aflatoxin M1 in Breast Milk, Cow Milk and Milk Products in Minna, Nigeria and their Predisposing Factors. Biochem. Anal. Biochem. 2016, 5, 4. [CrossRef]

84. Ware, L.Y.; Durand, N.; Nikiema, P.A.; Alter, P.; Fontana, A.; Montet, D.; Barro, N. Occurrence of mycotoxins in commercial infant formulas locally produced in Ouagadougou (Burkina Faso). Food Control 2017, 73, 518-523. [CrossRef]

85. Liu, Y.; Lu, Y.; Wang, L.; Chang, F.; Yang, L. Survey of 11 mycotoxins in wheat flour in Hebei province, China. Food Addit. Contam. Part B Surveill. 2015, 8, 250-254. [CrossRef] [PubMed]

86. Lai, X.; Liu, R.; Ruan, C.; Zhang, H.; Liu, C. Occurrence of aflatoxins and ochratoxin A in rice samples from six provinces in China. Food Control 2014, 50, 401-404. [CrossRef]

87. Xing, F.; Liu, X.; Wang, L.; Selvaraj, J.N.; Jin, N.; Wang, Y.; Zhao, Y.; Liu, Y. Distribution and variation of fungi and major mycotoxins in pre- and post-nature drying maize in North China Plain. Food Control 2017, 80, 244-251. [CrossRef]

88. Golge, O.; Hepsag, F.; Kabak, B. Determination of aflatoxins in walnut sujuk and Turkish delight by HPLC-FLD method. Food Control 2016, 59, 731-736. [CrossRef] 
89. Yilmaz, S.Ö. The contamination rate of aflatoxins in ground red peppers, dried figs, walnuts without shell and seedless black raisins commercialized in Sakarya City Center, Turkey. Ital. J. Food Sci. 2017, 29, 591-598.

90. Lippolis, V.; Irurhe, O.; Porricelli, A.C.R.; Cortese, M.; Schena, R.; Imafidon, T.; Oluwadun, A.; Pascale, M. Natural co-occurrence of aflatoxins and ochratoxin A in ginger (Zingiber officinale) from Nigeria. Food Control 2017, 73, 1061-1067. [CrossRef]

91. Amri, E. Aflatoxin and Fumonisin Contamination of Sun-Dried Sweet Potato (Ipomoea batatas L.) Chips in Kahama District, Tanzania. J. Appl. Environ. Microbiol. 2016, 4, 55-62.

92. Bolechová, M.; Benešová, K.; Běláková, S.; Čáslavský, J.; Pospíchalová, M.; Mikulíková, R. Determination of seventeen mycotoxins in barley and malt in the Czech Republic. Food Control 2015, 47, 108-113. [CrossRef]

93. Alhamoud, Y.; Yang, D.; Kenston, S.S.F.; Liu, G.; Liu, L.; Zhou, H.; Ahmed, F.; Zhaoa, J. Advances in biosensors for the detection of ochratoxin A: Bio-receptors, nanomaterials, and their applications. Biosens. Bioelectron. 2019, 141, 111418. [CrossRef]

94. Temesgen, A.; Teshome, G. Major mycotoxins occurrence, prevention and control approaches. Biotechnol. Mol. Biol. Rev. 2018, 12, 1-11. [CrossRef]

95. Limay-Rios, V.; Miller, J.D.; Schaafsma, A.W. Occurrence of Penicillium verrucosum, ochratoxin A, ochratoxin $\mathrm{B}$ and citrinin in on-farm stored winter wheat from the Canadian Great Lakes Region. PLoS ONE 2017, 12, e0181239. [CrossRef] [PubMed]

96. Zhao, Y.; Yuan, Y.-C.; Bai, X.-L.; Liu, Y.-M.; Wu, G.-F.; Yang, F.-S.; Liao, X. Multi-mycotoxins analysis in liquid milk by UHPLC-Q-Exactive HRMS after magnetic solid-phase extraction based on PEGylated multi-walled carbon nanotubes. Food Chem. 2020, 305, 125429. [CrossRef] [PubMed]

97. Mannaa, M.; Kim, K.D. Influence of temperature and water activity on deleterious fungi and mycotoxin production during grain storage. Mycobiology 2017, 45, 240-254. [CrossRef] [PubMed]

98. Joint Food and Agriculture Organization; World Health Organization Expert Committee on Food Additives (JECFA). Evaluation of Certain Food Additives and Contaminants: Fifty-Fifth Report of the JOINT/FAO/WHO Expert Committee on Food Additives; World Health Organization: Geneva, Switzerland, 2001; p. 701.

99. European Food Safety Authority. Opinion of the Scientific Panel on Contaminants in the Food Chain on a Request From the Commission Related To Ochratoxin a in Food. EFSA J. 2006, 365, 1-56.

100. Arrúa, A.A.; Mendes, J.M.; Arrúa, P.; Ferreira, F.P.; Caballero, G.; Cazal, C.; Kohli, M.M.; Peralta, I.; Ulke, G.; Ríos, D.F. Occurrence of Deoxynivalenol and Ochratoxin A in Beers and Wines Commercialized in Paraguay. Toxins 2019, 11, 308. [CrossRef]

101. Balendres, M.A.; Karlovsky, P.; Cumagun, C.J.R. Mycotoxigenic Fungi and Mycotoxins in Agricultural Crop Commodities in the Philippines: A Review. Foods 2019, 8, 8070249. [CrossRef]

102. Kedjebo, K.B.D.; Guehi, T.S.; Kouakou, B.; Durand, N.; Aguilar, P.; Fontana, A.; Montet, D. Effect of post-harvest treatments on the occurrence of ochratoxin a in raw cocoa beans. Food Addit. Contam. Part A Chem. Anal. Control Expo. Risk Assess. 2015, 33, 157-166. [CrossRef]

103. Naz, N.; Kashif, A.; Kanwal, K.; Ajaz, H. Incidence of mycotoxins in local and branded samples of chocolates marketed in Pakistan. J. Food Qual. 2017, 2017, 1947871. [CrossRef]

104. Meftah, S.; Abid, S.; Dias, T.; Rodrigues, P. Mechanisms underlying the effect of commercial starter cultures and a native yeast on ochratoxin A production in meat products. LWT 2020, 117, 108611. [CrossRef]

105. Eskola, M.; Kos, G.; Elliott, C.T.; Hajšlová, J.; Mayar, S.; Krska, R. Worldwide contamination of food-crops with mycotoxins: Validity of the widely cited 'FAO estimate' of 25\%. Crit. Rev. Food Sci. Nutr. 2019, 59, 1-17. [CrossRef]

106. Duarte, S.C.; Pena, A.; Lino, C.M. A review on ochratoxin A occurrence and effects of processing of cereal and cereal derived food products. Food Microbiol. 2010, 27, 187-198. [CrossRef] [PubMed]

107. Zhang, X.; Li, J.; Zong, N.; Zhou, Z.; Ma, L. Ochratoxin A in dried vine fruits from Chinese markets. Food Addit. Contam. Part B Surveill. 2014, 7, 157-161. [CrossRef] [PubMed]

108. Wei, D.; Wang, Y.; Jiang, D.; Feng, X.; Li, J.; Wang, M. Survey of alternaria toxins and other mycotoxins in dried fruits in China. Toxins 2017, 9, 200. [CrossRef] [PubMed]

109. Darouj, E.; Massouh, L.; Ghanem, I. Investigation of ochratoxin A in Syrian consumed baby foods. Food Control 2016, 62, 97-103. [CrossRef]

110. Tonon, K.M.; Reiter, M.G.R.; Savi, G.D.; Scussel, V.M. Human milk AFM1, OTA, and DON evaluation by liquid chromatography tandem mass specrometry and their relation to the Southern Brazil nursing mothers' diet. J. Food Saf. 2018, 38, 1-8. [CrossRef] 
111. Çă̆indi, Ö.; Gürhayta, O.F. Aflatoxins and ochratoxin A in dried eggplant and green bell pepper. Food Control 2016, 70, 216-220. [CrossRef]

112. Alkadri, D.; Rubert, J.; Prodi, A.; Pisi, A.; Mañes, J.; Soler, C. Natural co-occurrence of mycotoxins in wheat grains from Italy and Syria. Food Chem. 2014, 157, 111-118. [CrossRef]

113. Chen, F.; Luan, C.; Wang, L.; Wang, S.; Shao, L. Simultaneous determination of six mycotoxins in peanut by high-performance liquid chromatography with a fluorescence detector. J. Sci. Food Agric. 2017, 97, 1805-1810. [CrossRef]

114. Ul Hassan, Z.; Al Thani, R.A.; Atia, F.; Al Meer, S.; Migheli, Q.; Jaoua, S. Co-occurrence of mycotoxins in commercial formula milk and cereal-based baby food on the Qatar market. Food Addit. Contam. Part B Surveill. 2018, 11, 191-197. [CrossRef]

115. Gherbawy, Y.; Shebany, Y. Mycobiota, total aflatoxins and ochratoxin a of cardamom pods. Food Sci. Technol. Res. 2018, 24, 87-96. [CrossRef]

116. Benites, A.J.; Fernandes, M.; Boleto, A.R.; Azevedo, S.; Silva, S.; Leitão, A.L. Occurrence of ochratoxin A in roasted coffee samples commercialized in Portugal. Food Control 2017, 73, 1223-1228. [CrossRef]

117. Nielsen, K.F.; Ngemela, A.F.; Jensen, L.B.; De Medeiros, L.S.; Rasmussen, P.H. UHPLC-MS/MS determination of ochratoxin a and fumonisins in coffee using QuEChERS extraction combined with mixed-mode SPE purification. J. Agric. Food Chem. 2015, 63, 1029-1034. [CrossRef] [PubMed]

118. Franco, L.T.; Petta, T.; Rottinghaus, G.E.; Bordind, K.; Gomese, G.A.; Alvito, P.; Assunção, R.; Oliveira, C.A.F. Assessment of mycotoxin exposure and risk characterization using occurrence data in foods and urinary biomarkers in Brazil. Food Chem. Toxicol. 2019, 128, 21-34. [CrossRef] [PubMed]

119. Ingenbleek, L.; Sulyok, M.; Adegboye, A.; Hossou, S.E.; Koné, A.Z.; Oyedele, A.D.; Kisito, C.S.K.J.; Dembélé, Y.K.; Eyangoh, S.; Verger, P.; et al. Regional sub-saharan Africa total diet study in benin, cameroon, mali and nigeria reveals the presence of 164 mycotoxins and other secondary metabolites in foods. Toxins 2019, 11, 54. [CrossRef] [PubMed]

120. Sadiq, F.A.; Yan, B.; Tian, F.; Zhao, J.; Zhang, H.; Chen, W. Lactic Acid Bacteria as Antifungal and Anti-Mycotoxigenic Agents: A Comprehensive Review. Compr. Rev. Food Sci. Food Saf. 2019, 18, 1403-1436. [CrossRef]

121. Bullerman, L.B.; Bianchini, A. Stability of mycotoxins during food processing. Int. J. Food Microbiol. 2007, 119, 140-146. [CrossRef]

122. Perši, N.; Pleadin, J.; Kovačević, D.; Scortichini, G.; Milone, S. Ochratoxin A in raw materials and cooked meat products made from OTA-treated pigs. Meat Sci. 2014, 96, 203-210. [CrossRef]

123. Rheeder, J.P.; Marasas, W.F.O.; Vismer, H.F. Production of Fumonisin Analogs by Fusarium Species. Appl. Environ. Microbiol. 2002, 68, 2101-2105. [CrossRef]

124. Mogensen, J.M.; Frisvad, J.C.; Thrane, U.; Nielsen, K.F. Production of fumonisin B2 and B4 by aspergillus niger on grapes and raisins. J. Agric. Food Chem. 2010, 58, 954-958. [CrossRef]

125. Alberts, J.F.; van Zyl, W.H.; Gelderblom, W.C.A. Biologically based methods for control of fumonisin-producing Fusarium species and reduction of the fumonisins. Front. Microbiol. 2016, 7, 201600548. [CrossRef]

126. Joint Food and Agriculture Organization; World Health Organization Expert Committee on Food Additives (JECFA). Co-Exposure of Fumonisins with Aflatoxins; Food Safety Digest; World Health Organization: Geneva, Switzerland, 2018; pp. 1-4.

127. Marasas, W.F.; Kellerman, T.S.; Gelderblom, W.C.; Coetzer, J.A.; Thiel, P.G.; van der Lugt, J.J. Leukoencephalomalacia in a horse induced by fumonisin B1 isolated from Fusarium moniliforme. Onderstepoort J. Vet. Res. 1988, 55, 197-203.

128. Haschek, W.M.; Motelin, G.; Ness, D.K.; Harlin, K.S.; Hall, W.F.; Vesonder, R.F.; Peterson, R.E.; Beasley, V.R. Characterization of fumonisin toxicity in orally and intravenously dosed swine. Mycopathologia 1992, 117, 83-96. [CrossRef] [PubMed]

129. WHO (World Health Organization). Safety evaluation of certain mycotoxins in food (WHO food additives series 47). In International Programme on Chemical Safety; World Health Organization: Geneva, Switzerland, 2001; pp. 103-279.

130. Anfossi, L.; Giovannoli, C.; Baggiani, C. Mycotoxin detection. Curr. Opin. Biotechnol. 2016, 37, $120-126$. [CrossRef] [PubMed] 
131. Li, L.; Chen, W.; Li, H.; Iqbal, J.; Zhu, Y.; Wu, T.; Du, Y. Rapid determination of fumonisin (FB1) by syringe SPE coupled with solid-phase fluorescence spectrometry. Spectrochim. Acta Part A Mol. Biomol. Spectrosc. 2020, 226, 117549. [CrossRef] [PubMed]

132. Cendoya, E.; Nichea, M.J.; Monge, M.P.; Sulyok, M.; Chiacchiera, S.M.; Ramirez, M.L. Fumonisin occurrence in wheat-based products from Argentina. Food Addit. Contam. Part B Surveill. 2019, 12, 31-37. [CrossRef] [PubMed]

133. Cendoya, E.; Chiotta, M.L.; Zachetti, V.; Chulze, S.N.; Ramirez, M.L. Fumonisins and fumonisin-producing Fusarium occurrence in wheat and wheat by products: A review. J. Cereal Sci. 2018, 80, 158-166. [CrossRef]

134. Dall'Asta, C.; Battilani, P. Fumonisins and their modified forms, a matter of concern in future scenario? World Mycotoxin J. 2016, 9, 727-739. [CrossRef]

135. Stępień, Ł.; Waśkiewicz, A.; Urbaniak, M. Wildly Growing Asparagus (Asparagus officinalis L.) Hosts Pathogenic Fusarium Species and Accumulates Their Mycotoxins. Microb. Ecol. 2016, 71, 927-937. [CrossRef]

136. Al-Taher, F.; Cappozzo, J.; Zweigenbaum, J.; Lee, H.J.; Jackson, L.; Ryu, D. Detection and quantitation of mycotoxins in infant cereals in the U.S. market by LC-MS/MS using a stable isotope dilution assay. Food Control 2017, 72, 27-35. [CrossRef]

137. Kos, J.; Hajnal, E.J.; Škrinjar, M.; Mišan, A.; Mandić, A.; Jovanov, P.; Milovanović, I. Presence of Fusarium toxins in maize from Autonomous Province of Vojvodina, Serbia. Food Control 2014, 46, 98-101. [CrossRef]

138. Li, F.; Jiang, D.; Zheng, F.; Chen, J.; Li, W. Fumonisins B1, B2 and B3 in corn products, wheat flour and corn oil marketed in Shandong province of China. Food Addit. Contam. Part B Surveill. 2015, 8, 169-174. [CrossRef] [PubMed]

139. Mendes, G.D.R.L.; Reis, T.A.D.; Corrêa, B.; Badiale-Furlong, E. Mycobiota and occurrence of Fumonisin B1 in wheat harvested in Southern Brazil. Ciênc. Rural 2015, 45, 1050-1057. [CrossRef]

140. Amato, B.; Pfohl, K.; Tonti, S.; Nipoti, P.; Dastjerdi, R.; Pisi, A.; Karlovsky, P.; Prodi, A. Fusarium proliferatum and fumonisin B1 co-occur with Fusarium species causing Fusarium Head Blight in durum wheat in Italy. J. Appl. Bot. Food Qual. 2015, 88, 228-233.

141. Pereira, V.L.; Fernandes, J.O.; Cunha, S.C. Comparative assessment of three cleanup procedures after QuEChERS extraction for determination of trichothecenes (type A and type B) in processed cereal-based baby foods by GC-MS. Food Chem. 2015, 182, 143-149. [CrossRef]

142. Ferrigo, D.; Raiola, A.; Causin, R. Fusarium toxins in cereals: Occurrence, legislation, factors promoting the appearance and their management. Molecules 2016, 21, 21050627. [CrossRef]

143. Krska, R.; Malachova, A.; Berthiller, F.; van Egmond, H.P. Determination of T-2 and HT-2 toxins in food and feed: An update. World Mycotoxin J. 2014, 7, 131-142. [CrossRef]

144. European Food Safety Authority. Scientific Opinion on the risks for animal and public health related to the presence of T-2 and HT-2 toxin in food and feed. EFSA J. 2011, 9, 2481. [CrossRef]

145. Nolan, P.; Auer, S.; Spehar, A.; Elliott, C.T.; Campbell, K. Current trends in rapid tests for mycotoxins. Food Addit. Contam. Part A Chem. Anal. Control Expo. Risk Assess. 2019, 36, 800-814. [CrossRef]

146. Pascari, X.; Marín, S.; Ramos, A.J.; Molino, F.; Sanchis, V. Deoxynivalenol in cereal-based baby food production process. A review. Food Control 2019, 99, 11-20. [CrossRef]

147. Bianchini, A.; Horsley, R.; Jack, M.M.; Kobielush, B.; Ryu, D.; Tittlemier, S.; Wilson, W.W.; Abbas, H.K.; Abel, S.; Harrison, G.; et al. DON Occurrence in Grains: A North American Perspective. Cereal Foods World 2015, 60. [CrossRef]

148. Ji, F.; Xu, J.; Liu, X.; Yin, X.; Shi, J. Natural occurrence of deoxynivalenol and zearalenone in wheat from Jiangsu province, China. Food Chem. 2014, 157, 393-397. [CrossRef] [PubMed]

149. Mishra, S.; Srivastava, S.; Dewangan, J.; Divakar, A.; Rath, S.K. Global occurrence of deoxynivalenol in food commodities and exposure risk assessment in humans in the last decade: A survey. Crit. Rev. Food Sci. Nutr. 2019, 59, 1-29. [CrossRef] [PubMed]

150. Joint Food and Agriculture Organization; World Health Organization Expert Committee on Food Additives (JECFA). Evaluation of Certain Food Additives and Contaminants (Seventy-third Report of the Joint FAO/WHO Expert Committee on Food Current Additives); WHO: Geneva, Switzerland, 2010; p. 227.

151. European Food Safety Authority. Risks to human and animal health related to the presence of deoxynivalenol and its acetylated and modified forms in food and feed. EFSA J. 2017, 15, 4718. 
152. Chilaka, C.A.; De Boevre, M.; Atanda, O.O.; De Saeger, S. Occurrence of Fusarium mycotoxins in cereal crops and processed products (Ogi) from Nigeria. Toxins 2016, 8, 342. [CrossRef] [PubMed]

153. Oueslati, S.; Berrada, H.; Mañes, J.; Juan, C. Presence of mycotoxins in Tunisian infant foods samples and subsequent risk assessment. Food Control 2018, 84, 362-369. [CrossRef]

154. Pleadin, J.; Staver, M.M.; Markov, K.; Frece, J.; Zadravec, M.; Jaki, V.; Krupić, I.; Vahčić, N. Mycotoxins in organic and conventional cereals and cereal products grown and marketed in Croatia. Mycotoxin Res. 2017, 33, 219-227. [CrossRef] [PubMed]

155. Levasseur-Garcia, C. Updated overview of infrared spectroscopy methods for detecting mycotoxins on cereals (corn, wheat, and barley). Toxins 2018, 10, 10010038. [CrossRef]

156. Chen, Y.; Kistler, H.C.; Ma, Z. Fusarium graminearum Trichothecene Mycotoxins: Biosynthesis, Regulation, and Management. Annu. Rev. Phytopathol. 2019, 57, 15-39. [CrossRef]

157. Han, Z.; Nie, D.; Ediage, E.N.; Yang, X.; Wang, J.; Chen, B.; Li, S.; On, S.L.W.; De Saeger, S.; Wu, A. Cumulative health risk assessment of co-occurring mycotoxins of deoxynivalenol and its acetyl derivatives in wheat and maize: Case study, Shanghai, China. Food Chem. Toxicol. 2014, 74, 334-342. [CrossRef]

158. Urusov, A.E.; Gubaidullina, M.K.; Petrakova, A.V.; Zherdev, A.V.; Dzantiev, B.B. A new kind of highly sensitive competitive lateral flow immunoassay displaying direct analyte-signal dependence. Application to the determination of the mycotoxin deoxynivalenol. Microchim. Acta 2018, 185, 29. [CrossRef]

159. Majeed, S.; De Boevre, M.; De Saeger, S.; Rauf, W.; Tawab, A.; Habib, F.-E.; Rahman, M.; Iqbal, M. Multiple mycotoxins in rice: Occurrence and health risk assessment in children and adults of Punjab, Pakistan. Toxins 2018, 10, 77. [CrossRef] [PubMed]

160. De Lima Rocha, D.F.; dos Santos Oliveira, M.; Furlong, E.B.; Junges, A.; Paroul, N.; Valduga, E.; Toniazzo, G.B.; Zeni, J.; Cansian, R.L. Evaluation of the TLC quantification method and occurrence of deoxynivalenol in wheat flour of southern Brazil. Food Addit. Contam. Part A Chem. Anal. Control Expo. Risk Assess. 2017, 34, 2220-2229. [CrossRef] [PubMed]

161. Bertuzzi, T.; Leggieri, M.C.; Battilani, P.; Pietri, A. Co-occurrence of type A and B trichothecenes and zearalenone in wheat grown in northern Italy over the years 2009-2011. Food Addit. Contam. Part B Surveill. 2014, 7, 273-281. [CrossRef] [PubMed]

162. Savi, G.D.; Piacentini, K.C.; Tibola, C.S.; Scussel, V.M. Mycoflora and deoxynivalenol in whole wheat grains (Triticum aestivum L.) from Southern. Food Addit. Contam. Part B. 2014, 7, 232-237. [CrossRef]

163. Darsanaki, R.K.; Issazadeh, K.; Aliabadi, M.A.; Chakoosari, M.M.D. Occurrence of Deoxynivalenol (DON) in wheat flours in Guilan Province, northern Iran. Ann. Agric. Environ. Med. 2015, 22, 35-37. [CrossRef] [PubMed]

164. Nathanail, A.V.; Syvähuoko, J.; Malachová, A.; Jestoi, M.; Varga, E.; Michlmayr, H.; Adam, G.; Sieviläinen, E.; Berthiller, F.; Peltonen, K. Simultaneous determination of major type A and B trichothecenes, zearalenone and certain modified metabolites in Finnish cereal grains with a novel liquid chromatography-tandem mass spectrometric method. Anal. Bioanal. Chem. 2015, 407, 4745-4755. [CrossRef]

165. De Almeida, A.P.; Lamardo, L.C.A.; Shundo, L.; da Silva, S.A.; Navas, S.A.; Alaburda, J.; Ruvieri, V.; Sabino, M. Occurrence of deoxynivalenol in wheat flour, instant noodle and biscuits commercialised in Brazil. Food Addit. Contam. Part B Surveill. 2016, 9, 251-255. [CrossRef]

166. Calori-Domingues, M.A.; Bernardi, C.M.G.; Nardin, M.S.; de Souza, G.V.; dos Santos, F.G.R.; de Abreu Stein, M.; da Gloria, E.M.; dos Santos Dias, C.T.; de Camargo, A.C. Co-occurrence and distribution of deoxynivalenol, nivalenol and zearalenone in wheat from Brazil. Food Addit. Contam. Part B Surveill. 2016, 9, 142-151. [CrossRef]

167. Tralamazza, S.M.; Bemvenuti, R.H.; Zorzete, P.; De Souza Garcia, F.; Corrêa, B. Fungal diversity and natural occurrence of deoxynivalenol and zearalenone in freshly harvested wheat grains from Brazil. Food Chem. 2016, 196, 445-450. [CrossRef]

168. Tima, H.; Brückner, A.; Mohácsi-Farkas, C.; Kiskó, G. Fusarium mycotoxins in cereals harvested from Hungarian fields. Food Addit. Contam. Part B Surveill. 2016, 9, 127-131. [CrossRef]

169. Palacios, S.A.; Erazo, J.G.; Ciasca, B.; Lattanzio, V.M.T.; Reynoso, M.M.; Farnochi, M.C.; Torres, A.M. Occurrence of deoxynivalenol and deoxynivalenol-3-glucoside in durum wheat from Argentina. Food Chem. 2017, 230, 728-734. [CrossRef] [PubMed] 
170. Vogelgsang, S.; Musa, T.; Bänziger, I.; Kägi, A.; Bucheli, T.D.; Wettstein, F.E.; Pasquali, M.; Forrer, H.-R. Fusarium mycotoxins in Swiss wheat: A survey of growers' samples between 2007 and 2014 shows strong year and minor geographic effects. Toxins 2017, 9, 9080246. [CrossRef] [PubMed]

171. Silva, M.V.; Pante, G.C.; Romoli, J.C.Z.; de Souza, A.P.M.; da Rocha, G.H.O.; Ferreira, F.D.; Feijó, A.L.R.; Moscardi, S.M.P.; de Paula, K.R.; Bando, E.; et al. Occurrence and risk assessment of population exposed to deoxynivalenol in foods derived from wheat flour in Brazil. Food Addit. Contam. Part A Chem. Anal. Control Expo. Risk Assess. 2018, 35, 546-554. [CrossRef] [PubMed]

172. Bryła, M.; Ksieniewicz-Woźniak, E.; Waśkiewicz, A.; Szymczyk, K.; Jędrzejczak, R. Natural occurrence of nivalenol, deoxynivalenol, and deoxynivalenol-3-glucoside in polish winter wheat. Toxins 2018, 10, 10020081. [CrossRef]

173. Zhao, Y.; Guan, X.; Zong, Y.; Hua, X.; Xing, F.; Wang, Y.; Wang, F.; Liu, Y. Deoxynivalenol in wheat from the Northwestern region in China. Food Addit. Contam. Part B Surveill. 2018, 11, 281-285. [CrossRef]

174. Torović, L. Fusarium toxins in corn food products: A survey of the Serbian retail market. Food Addit. Contam. Part A Chem. Anal. Control Expo. Risk Assess. 2018, 35, 1596-1609. [CrossRef]

175. Piacentini, K.C.; Rocha, L.O.; Savi, G.D.; Carnielli-Queiroz, L.; Almeida, F.G.; Minella, E.; Corrêa, B. Occurrence of deoxynivalenol and zearalenone in brewing barley grains from Brazil. Mycotoxin Res. 2018, 34, 173-178. [CrossRef]

176. Gummadidala, P.M.; Omebeyinje, M.H.; Burch, J.A.; Chakraborty, P.; Biswas, P.K.; Banerjee, K.; Wang, Q.; Jesmin, R.; Mitra, C.; Moeller, P.D.R.; et al. Complementary feeding may pose a risk of simultaneous exposures to aflatoxin M1 and deoxynivalenol in Indian infants and toddlers: Lessons from a mini-survey of food samples obtained from Kolkata, India. Food Chem. Toxicol. 2019, 123, 9-15. [CrossRef]

177. Edwards, S.G. Impact of agronomic and climatic factors on the mycotoxin content of harvested oats in the United Kingdom. Food Addit. Contam. Part A Chem. Anal. Control Expo. Risk Assess. 2017, 34, 2230-2241. [CrossRef]

178. Hietaniemi, V.; Rämö, S.; Yli-Mattila, T.; Jestoi, M.; Peltonen, S.; Kartio, M.; Sieviläinen, E.; Koivisto, T.; Parikka, P. Updated survey of Fusarium species and toxins in Finnish cereal grains. Food Addit. Contam. Part A Chem. Anal. Control Expo. Risk Assess. 2016, 33, 831-848. [CrossRef]

179. Bryła, M.; Waśkiewicz, A.; Podolska, G.; Szymczyk, K.; Jędrzejczak, R.; Damaziak, K.; Sułek, A. Occurrence of 26 mycotoxins in the grain of cereals cultivated in Poland. Toxins 2016, 8, 8060160. [CrossRef] [PubMed]

180. Elaridi, J.; Yamani, O.; Al Matari, A.; Dakroub, S.; Attieh, Z. Determination of Ochratoxin A (OTA), Ochratoxin B (OTB), T-2, and HT-2 Toxins in Wheat Grains, Wheat Flour, and Bread in Lebanon by LC-MS/MS. Toxins 2019, 11, 471. [CrossRef] [PubMed]

181. Cano-Sancho, D.G.; Valle-Algarra, F.M.; Jiménez, M.; Burdaspal, P.; Legarda, T.M.; Ramos, A.J.; Sanchis, V.; Marín, S. Presence of trichothecenes and co-occurrence in cereal-based food from Catalonia (Spain). Food Control 2011, 22, 490-495. [CrossRef]

182. Rodrvguez-Carrasco, Y.; Berrada, H.; Font, G.; Mañes, J. Multi-mycotoxin analysis in wheat semolina using an acetonitrile-based extraction procedure and gas chromatography-tandem mass spectrometry. J. Chromatogr. A 2012, 1270, 28-40. [CrossRef]

183. Rai, A.; Das, M.; Tripathi, A. Occurrence and toxicity of a fusarium mycotoxin, zearalenone. Crit. Rev. Food Sci. Nutr. 2019, 59, 1-20. [CrossRef]

184. Zinedine, A.; Soriano, J.M.; Moltó, J.C.; Mañes, J. Review on the toxicity, occurrence, metabolism, detoxification, regulations and intake of zearalenone: An oestrogenic mycotoxin. Food Chem. Toxicol. 2007, 45, 1-18. [CrossRef]

185. European Food Safety Authority. Scientific Opinion on the risks for human and animal health related to the presence of modeified forms of certain mycotoxins in food and feed. EFSA J. 2011, 9, 2197. [CrossRef]

186. Habler, K.; Gotthardt, M.; Schüler, J.; Rychlik, M. Multi-mycotoxin stable isotope dilution LC-MS/MS method for Fusarium toxins in beer. Food Chem. 2017, 218, 447-454. [CrossRef]

187. Tamura, M.; Mochizuki, N.; Nagatomi, Y.; Harayama, K.; Toriba, A.; Hayakawa, K. A Method for Simultaneous Determination of 20 Fusarium Toxins in Cereals by High-Resolution Liquid Chromatography-Orbitrap Mass Spectrometry with a Pentafluorophenyl Column. Toxins 2015, 7, 1664-1682. [CrossRef]

188. Abdallah, M.F.; Girgin, G.; Baydar, T. Mycotoxin Detection in Maize, Commercial Feed, and Raw Dairy Milk Samples from Assiut City, Egypt. Vet. Sci. 2019, 6, 6020057. [CrossRef] 
189. Tulayakul, P.; Sugita-konishi, Y. Mycotoxin contamination in foodstuffs and feeds- health concerns in Thailand. Jpn. J. Vet. Res. 2017, 65, 173-183.

190. Nazari, F.; Sulyok, M.; Yazdanpanah, H.; Kobarfard, F.; Krska, R. A survey of mycotoxins in domestic rice in Iran by liquid chromatography tandem mass spectrometry. Toxicol. Mech. Method 2014, 1, 37-41. [CrossRef]

191. Morton, I.K.; Hall, J.M. Concise Dictionary of Pharmacological Agents: Properties and Synonyms; Springer Science \& Business Media: Berlin, Germany, 2012; p. 295.

192. Han, Z.; Jiang, K.; Fan, Z.; Di Mavungu, J.D.; Dong, M.; Guo, W.; Fan, K.; Campbell, K.; Zhao, Z.; Wu, Y. Multi-walled carbon nanotubes-based magnetic solid-phase extraction for the determination of zearalenone and its derivatives in maize by ultra-high performance liquid chromatography-tandem mass spectrometry. Food Control 2017, 79, 177-184. [CrossRef]

193. Ok, H.E.; Choi, S.W.; Kim, M.; Chun, H.S. HPLC and UPLC methods for the determination of zearalenone in noodles, cereal snacks and infant formula. Food Chem. 2014, 163, 252-257. [CrossRef] [PubMed]

194. Lanza, A.; da Silva, R.C.; dos Santos, I.D.; Pizzutti, I.R.; Cence, K.; Cansian, R.L.; Zeni, J.; Valduga, E. Mycotoxins' evaluation in wheat flours used in Brazilian bakeries. Food Sci. Biotechnol. 2019, 28, 931-937. [CrossRef]

195. Vaclavikova, M.; Malachova, A.; Veprikova, Z.; Dzuman, Z.; Zachariasova, M.; Hajslova, J. “Emerging” mycotoxins in cereals processing chains: Changes of enniatins during beer and bread making. Food Chem. 2013, 136, 750-757. [CrossRef] [PubMed]

196. European Food Safety Authority. Scientific Opinion on the risks to human and animal health related to the presence of beauvericin and enniatins in food and feed. EFSA J. 2014, 12, 3802. [CrossRef]

197. Gruber-Dorninger, C.; Novak, B.; Nagl, V.; Berthiller, F. Emerging Mycotoxins: Beyond Traditionally Determined Food Contaminants. J. Agric. Food Chem. 2017, 65, 7052-7070. [CrossRef]

198. Fraeyman, S.; Croubels, S.; Devreese, M.; Antonissen, G. Emerging fusarium and alternaria mycotoxins: Occurrence, toxicity and toxicokinetics. Toxins 2017, 9, 228. [CrossRef]

199. Luz, C.; Saladino, F.; Luciano, F.B.; Mañes, J.; Meca, G. Occurrence, toxicity, bioaccessibility and mitigation strategies of beauvericin, a minor Fusarium mycotoxin. Food Chem. Toxicol. 2017, 107, 430-439. [CrossRef]

200. Stanciu, O.; Juan, C.; Miere, D.; Loghin, F.; Mañes, J. Presence of enniatins and beauvericin in Romanian wheat samples: From raw material to products for direct human consumption. Toxins 2017, 9, 9060189. [CrossRef] [PubMed]

201. Quiles, J.M.; Saladino, F.; Mañes, J.; Fernández-Franzón, M.; Meca, G. Occurrence of mycotoxins in refrigerated pizza dough and risk assessment of exposure for the Spanish population. Food Chem. Toxicol. 2016, 94, $19-24$. [CrossRef] [PubMed]

202. Yoshinari, T.; Suzuki, Y.; Sugita-Konishi, Y.; Ohnishi, T.; Terajima, J. Occurrence of beauvericin and enniatins in wheat flour and corn grits on the Japanese market, and their co-contamination with type $\mathrm{B}$ trichothecene mycotoxins. Food Addit. Contam. Part A Chem. Anal. Control.Expo. Risk Assess. 2016, 33, 1620-1626. [CrossRef] [PubMed]

203. Sulyok, M.; Beed, F.; Boni, S.; Abass, A.; Mukunzi, A.; Krska, R. Quantitation of multiple mycotoxins and cyanogenic glucosides in cassava samples from Tanzania and Rwanda by an LC-MS/MS-based multi-toxin method. Food Addit. Contam. Part A Chem. Anal. Control Expo. Risk Assess. 2015, 32, 488-502. [CrossRef] [PubMed]

204. Nazari, F.; Sulyok, M.; Kobarfard, F.; Yazdanpanah, H.; Krska, R. Evaluation of Emerging Fusarium mycotoxins Beauvericin, Enniatins, Fusaproliferin and Moniliformin in Domestic Rice in Iran. Iran. J. Pharm. Res. 2013, 14, 505-512.

205. Blesa, J.; Moltó, J.C.; El Akhdari, S.; Mañes, J.; Zinedine, A. Simultaneous determination of Fusarium mycotoxins in wheat grain from Morocco by liquid chromatography coupled to triple quadrupole mass spectrometry. Food Control 2014, 46, 1-5. [CrossRef]

206. Varga, E.; Wiesenberger, G.; Hametner, C.; Ward, T.J.; Dong, Y.; Schöfbeck, D.; McCormick, S.; Broz, K.; Stückler, R.; Schuhmacher, R.; et al. New tricks of an old enemy: Isolates of Fusarium graminearum produce a type A trichothecene Mycotoxin. Environ. Microbiol. 2015, 17, 2588-2600. [CrossRef]

207. Venkatesh, N.; Keller, N.P. Mycotoxins in conversation with bacteria and fungi. Front. Microbiol. 2019, 10, 201900403. [CrossRef] 
208. Logrieco, A.; Rizzo, A.; Ferracane, R.; Ritieni, A. Occurrence of Beauvericin and Enniatins in Wheat Affected by Fusarium avenaceum Head Blight. Appl. Environ. Microbiol. 2002, 68, 82-85. [CrossRef]

209. Agriopoulou, S. Enniatins: An Emerging Food Safety Issue. EC Nutr. 2016, 3, 1142-1146.

210. Gunter, A.B.; Hermans, A.; Bosnich, W.; Johnson, D.A.; Harris, L.J.; Gleddie, S. Protein engineering of Saccharomyces cerevisiae transporter Pdr5p identifies key residues that impact Fusarium mycotoxin export and resistance to inhibition. Microbiologyopen 2016, 5, 979-991. [CrossRef] [PubMed]

211. Covarelli, L.; Beccari, G.; Prodi, A.; Generotti, S.; Etruschi, F.; Meca, G.; Juan, C.; Mañes, J. Biosynthesis of beauvericin and enniatins in vitro by wheat Fusarium species and natural grain contamination in an area of central Italy. Food Microbiol. 2015, 46, 618-626. [CrossRef] [PubMed]

212. Jajic, I.; Dudaš, T.; Krstovic, S.; Krska, R.; Sulyok, M.; Bagi, F.; Savic, Z.; Guljaš, D.; Stankov, A. Emerging Fusarium Mycotoxins Fusaproliferin, Beauvericin, Enniatins, and Moniliformin in Serbian Maize. Toxins 2019, 357, 1-14.

213. European Food Safety Authority. Scientific report on human and animal dietary exposure to ergot alkaloids. EFSA J. 2017, 15, 4902.

214. Shi, H.; Schwab, W.; Liu, N.; Yu, P. Major ergot alkaloids in naturally contaminated cool-season barley grain grown under a cold climate condition in western Canada, explored with near-infrared (NIR) and fourier transform mid-infrared (ATR-FT/MIR) spectroscopy. Food Control 2019, 102, 221-230. [CrossRef]

215. European Food Safety Authority. Panel on Contaminants in the Food Chain (CONTAM); Scientific O pinion on Ergot alkaloids in food and feed. EFSA J. 2012, 10, 2798.

216. Topi, D.; Jakovac-Strajn, B.; Pavšič-Vrtač, K.; Tavčar-Kalcher, G. Occurrence of ergot alkaloids in wheat from Albania. Food Addit. Contam. Part A Chem. Anal. Control Expo. Risk Assess. 2017, 34, 1333-1343. [CrossRef]

217. Tittlemier, S.A.; Drul, D.; Roscoe, M.; McKendry, T. Occurrence of Ergot and Ergot Alkaloids in Western Canadian Wheat and Other Cereals. J. Agric. Food Chem. 2015, 63, 6644-6650. [CrossRef]

218. Commission Recommendation, 2012/154/EU on the monitoring of the presence of ergot alkaloids in feed and food. Off. J. Eur. Union 2012, L77, 20-21.

219. Guo, Q.; Shao, B.; Du, Z.; Zhang, J. Simultaneous Determination of 25 Ergot Alkaloids in Cereal Samples by Ultraperformance Liquid Chromatography-Tandem Mass Spectrometry. J. Agric. Food Chem. 2016, 64, 7033-7039. [CrossRef]

220. Logrieco, A.; Moretti, A.; Solfrizzo, M. Alternaria toxins and plant diseases: An overview of origin, occurrence and risks. World Mycotoxin J. 2009, 2, 129-140. [CrossRef]

221. Sivagnanam, K.; Komatsu, E.; Rampitsch, C.; Perreault, H.; Gräfenhan, T. Rapid screening of Alternaria mycotoxins using MALDI-TOF mass spectrometry. J. Sci. Food Agric. 2017, 97, 357-361. [CrossRef] [PubMed]

222. European Food Safety Authority. Scientific Opinion on the risks for animal and public health related to the presence of Alternaria toxins in feed and food. EFSA J. 2011, 10, 2407.

223. Zwickel, T.; Klaffke, H.; Richards, K.; Rychlik, M. Development of a high performance liquid chromatography tandem mass spectrometry based analysis for the simultaneous quantification of various Alternaria toxins in wine, vegetable juices and fruit juices. J. Chromatogr. A 2016, 1455, 74-85. [CrossRef]

224. Romero Bernal, Á.R.; Reynoso, C.M.; García Londoño, V.A.; Broggi, L.E.; Resnik, S.L. Alternaria toxins in Argentinean wheat, bran, and flour. Food Addit. Contam. Part B Surveill. 2019, 12, 24-30. [CrossRef]

225. Pero, R.W.; Posner, H.; Blois, M.; Harvan, D.; Spalding, J.W. Toxicity of metabolites produced by the "Alternaria". Environ. Health Perspect. 1973, 4, 87-94. [CrossRef]

226. Tittlemier, S.A.; Blagden, R.; Chan, J.; Gaba, D.; Mckendry, T.; Pleskach, K.; Roscoe, M. Fusarium and Alternaria mycotoxins present in Canadian wheat and durum harvest samples. Can. J. Plant Pathol. 2019, 41, 403-414. [CrossRef]

227. López, P.; Venema, D.; Mol, H.; Spanjer, M.; de Stoppelaar, J.; Pfeiffer, E.; de Nijs, M. Alternaria toxins and conjugates in selected foods in the Netherlands. Food Control 2016, 69, 153-159. [CrossRef]

228. Sanzani, S.M.; Gallone, T.; Garganese, F.; Caruso, A.G.; Amenduni, M.; Ippolito, A. Contamination of fresh and dried tomato by Alternaria toxins in southern Italy. Food Addit. Contam. Part A Chem. Anal. Control Expo. Risk Assess. 2019, 36, 789-799. [CrossRef]

229. Xu, W.; Han, X.; Li, F.; Zhang, L. Natural occurrence of Alternaria toxins in the 2015 wheat from anhui province, China. Toxins 2016, 8, 308. [CrossRef] 
230. Zhao, K.; Shao, B.; Yang, D.; Li, F.; Zhu, J. Natural occurrence of Alternaria toxins in wheat-based products and their dietary exposure in China. PLoS ONE 2015, 10, 1-11. [CrossRef] [PubMed]

231. Gambacorta, L.; Magistá, D.; Perrone, G.; Murgolo, S.; Logrieco, A.F.; Solfrizzo, M. Co-occurrence of toxigenic moulds, aflatoxins, ochratoxin A, Fusarium and Alternaria mycotoxins in fresh sweet peppers (Capsicum annuum) and their processed products. World Mycotoxin J. 2018, 11, 159-173. [CrossRef]

232. Prelle, A.; Spadaro, D.; Garibaldi, A.; Gullino, M.L. A new method for detection of five alternaria toxins in food matrices based on LC-APCI-MS. Food Chem. 2013, 140, 161-167. [CrossRef] [PubMed]

233. Walravens, J.; Mikula, H.; Rychlik, M.; Asamd, S.; Ediagea, E.N.; Di Mavungua, J.D.; Landschoote, A.V.; Vanhaeckef, L.; De Saeger, S. Development and validation of an ultra-high-performance liquid chromatography tandem mass spectrometric method for the simultaneous determination of free and conjugated Alternaria toxins in cereal-based foodstuffs. J. Chromatogr. A 2014, 1372, 91-101. [CrossRef]

234. Vidal, A.; Ouhibi, S.; Ghali, R.; Hedhili, A.; De Saeger, S.; De Boevre, M. The mycotoxin patulin: An updated short review on occurrence, toxicity and analytical challenges. Food Chem. Toxicol. 2019, 129, $249-256$. [CrossRef]

235. Zhong, L.; Carere, J.; Lu, Z.; Lu, F.; Zhou, T. Patulin in apples and apple-based food products: The burdens and the mitigation strategies. Toxins 2018, 10, 475. [CrossRef]

236. Chandra, S.; Patras, A.; Pokharel, B.; Bansode, R.R.; Begum, A.; Sasges, M. Patulin degradation and cytotoxicity evaluation of UV irradiated apple juice using human peripheral blood mononuclear cells. J. Food Process Eng. 2017, 40, 1-9. [CrossRef]

237. Torović, L.; Dimitrov, N.; Assunção, R.; Alvito, P. Risk assessment of patulin intake through apple-based food by infants and preschool children in Serbia. Food Addit. Contam. Part A Chem. Anal. Control Expo. Risk Assess. 2017, 34, 2023-2032. [CrossRef]

238. Wei, D.-M.; Xu, J.; Dong, F.-S.; Liu, X.-G.; Wu, X.-H.; Zheng, Y.-Q. Penicillium and patulin distribution in pears contaminated with Penicillium expansum. Determination of patulin in pears by UHPLC-MS/MS. J. Integr. Agric. 2017, 16, 1645-1651. [CrossRef]

239. Iqbal, S.Z.; Malik, S.; Asi, M.R.; Selamat, J.; Malik, N. Natural occurrence of patulin in different fruits, juices and smoothies and evaluation of dietary intake in Punjab, Pakistan. Food Control 2018, 84, 370-374. [CrossRef]

240. Ji, X.; Li, R.; Yang, H.; Qi, P.; Xiao, Y.; Qian, M. Occurrence of patulin in various fruit products and dietary exposure assessment for consumers in China. Food Control 2017, 78, 100-107. [CrossRef]

241. Yang, Q.; Wang, J.; Zhang, H.; Li, C.; Zhang, X. Ochratoxin A is degraded by Yarrowia lipolytica and generates non-toxic degradation products. World Mycotoxin J. 2016, 9, 269-278. [CrossRef]

242. Hammami, W.; Al Thani, R.; Fiori, S.; Al-Meer, S.; Atia, F.A.; Rabah, D.; Migheli, Q.; Jaoua, S. Patulin and patulin producing Penicillium spp. Occurrence in apples and apple-based products including baby food. J. Infect. Dev. Ctries. 2017, 11, 343-349. [CrossRef] [PubMed]

243. Zouaoui, N.; Sbaii, N.; Bacha, H.; Abid-Essefi, S. Occurrence of patulin in various fruit juice marketed in Tunisia. Food Control 2015, 51, 356-360. [CrossRef]

244. Torović, L.; Dimitrov, N.; Lopes, A.; Martins, C.; Alvito, P.; Assunção, R. Patulin in fruit juices: Occurrence, bioaccessibility, and risk assessment for Serbian population. Food Addit. Contam. Part A Chem. Anal. Control Expo. Risk Assess. 2018, 35, 985-995. [CrossRef]

245. Oteiza, J.M.; Khaneghah, A.M.; Campagnoll, F.B.; Granato, D.; Mahmoudi, M.R.; Sant'Ana, A.S.; Gianuzzi, L. Influence of production on the presence of patulin and ochratoxin A in fruit juices and wines of Argentina. LWT Food Sci. Technol. 2017, 80, 200-207. [CrossRef]

246. Lee, T.P.; Sakai, R.; Manaf, N.A.; Rodhi, A.M.; Saad, B. High performance liquid chromatography method for the determination of patulin and 5-hydroxymethylfurfural in fruit juices marketed in Malaysia. Food Control 2014, 38, 142-149. [CrossRef]

247. Juan, C.; Raiola, A.; Mañes, J.; Ritieni, A. Presence of mycotoxin in commercial infant formulas and baby foods from Italian market. Food Control 2014, 39, 227-236. [CrossRef]

248. Luo, Y.; Liu, X.; Li, J. Updating techniques on controlling mycotoxins-A review. Food Control 2018, 89, 123-132. [CrossRef]

249. Adebiyi, J.A.; Kayitesi, E.; Adebo, O.A.; Changwa, R.; Njobeh, P.B. Food fermentation and mycotoxin detoxification: An African perspective. Food Control 2019, 106, 106731. [CrossRef] 
250. Alberts, J.F.; Lilly, M.; Rheeder, J.P.; Burger, H.M.; Shephard, G.S.; Gelderblom, W.C.A. Technological and community-based methods to reduce mycotoxin exposure. Food Control 2017, 73, 101-109. [CrossRef]

251. Sarrocco, S.; Vannacci, G. Preharvest application of beneficial fungi as a strategy to prevent postharvest mycotoxin contamination: A review. Crop Prot. 2018, 110, 160-170. [CrossRef]

252. Sarrocco, S.; Mauro, A.; Battilani, P. Use of Competitive Filamentous Fungi as anAlternative Approach for Mycotoxin Risk Reductionin Staple Cereals: State of Art and Future Perspectives. Toxins 2019, 11, 701. [CrossRef] [PubMed]

253. Lyagin, I.; Efremenko, E. Enzymes for detoxification of various mycotoxins: Origins and mechanisms of catalytic action. Molecules 2019, 24, 2362. [CrossRef] [PubMed]

254. Wang, L.; Wu, J.; Liu, Z.; Shi, Y.; Liu, J.; Xu, X.; Hao, S.; Mu, P.; Deng, F.; Deng, Y. Aflatoxin B1 degradation and detoxification by Escherichia coli CG1061 isolated from chicken cecum. Front. Pharmacol. 2019, 9, 1-9. [CrossRef] [PubMed]

255. Chilaka, C.A.; De Boevre, M.; Atanda, O.O.; De Saeger, S. The status of fusarium mycotoxins in sub-Saharan Africa: A review of emerging trends and post-harvest mitigation strategies towards food control. Toxins 2017, 9, 9010019. [CrossRef] [PubMed]

256. Karlovsky, P.; Suman, M.; Berthiller, F.; De Meester, J.; Eisenbrand, G.; Perrin, I.; Oswald, I.P.; Speijers, G.; Chiodini, A.; Recker, T.; et al. Impact of food processing and detoxification treatments on mycotoxin contamination. Mycotoxin Res. 2016, 32, 179-205. [CrossRef]

257. Neme, K.; Mohammed, A. Mycotoxin occurrence in grains and the role of postharvest management as a mitigation strategies. A review. Food Control 2017, 78, 412-425. [CrossRef]

258. Shanakhat, H.; Sorrentino, A.; Raiola, A.; Romano, A.; Masi, P.; Cavella, S. Current methods for mycotoxins analysis and innovative strategies for their reduction in cereals: An overview. J. Sci. Food Agric. 2018, 98, 4003-4013. [CrossRef]

259. Rushing, B.R.; Selim, M.I. Aflatoxin B1: A review on metabolism, toxicity, occurrence in food, occupational exposure, and detoxification methods. Food Chem. Toxicol. 2019, 124, 81-100. [CrossRef]

260. Gonçalves, A.; Gkrillas, A.; Dorne, J.L.; Dall'Asta, C.; Palumbo, R.; Lima, N.; Battilani, P.; Venâncio, A.; Giorni, P. Pre- and Postharvest Strategies to Minimize Mycotoxin Contamination in the Rice Food Chain. Compr. Rev. Food Sci. Food Saf. 2019, 18, 441-454. [CrossRef]

261. Kalagatur, N.K.; Kamasani, J.R.; Mudili, V. Assessment of detoxification efficacy of irradiation on zearalenone mycotoxin in various fruit juices by response surface methodology and elucidation of its in-vitro toxicity. Front. Microbiol. 2018, 9, 1-13. [CrossRef] [PubMed]

262. Hojnik, N.; Cvelbar, U.; Tavčar-Kalcher, G.; Walsh, J.L.; Križaj, I. Mycotoxin decontamination of food: Cold atmospheric pressure plasma versus "classic" decontamination. Toxins 2017, 9, 9050151. [CrossRef] [PubMed]

263. Wielogorska, E.; Ahmed, Y.; Meneely, J.; Graham, W.G.; Elliott, C.T.; Gilmore, B.F. A holistic study to understand the detoxification of mycotoxins in maize and impact on its molecular integrity using cold atmospheric plasma treatment. Food Chem. 2019, 301, 125281. [CrossRef] [PubMed]

264. Basaran, P.; Basaran-Akgul, N.; Oksuz, L. Elimination of Aspergillus parasiticus from nut surface with low pressure cold plasma (LPCP) treatment. Food Microbiol. 2008, 25, 626-632. [CrossRef] [PubMed]

265. Schlüter, O.; Ehlbeck, J.; Hertel, C.; Habermeyer, M.; Roth, A.; Engel, K.-H.; Holzhauser, T.; Knorr, D.; Eisenbrand, G. Opinion on the use of plasma processes for treatment of foods. Mol. Nutr. Food Res. 2013, 57, 920-927. [CrossRef]

266. Hojnik, N.; Modic, M.; Tavčar-Kalcher, G.; Babič, J.; Walsh, J.L.; Cvelbar, U. Mycotoxin Decontamination Efficacy of Atmospheric Pressure Air Plasma. Toxins 2019, 11, 11040219. [CrossRef]

267. Kamle, M.; Mahato, D.K.; Devi, S.; Lee, K.E.; Kang, S.G.; Kumar, P. Fumonisins: Impact on Agriculture, Food, and Human Health and their Management Strategies. Toxins 2019, 11, 328. [CrossRef]

268. González Pereyra, M.L.; Martínez, M.P.; Cavaglieri, L.R. Presence of aiiA homologue genes encoding for $\mathrm{N}$-Acyl homoserine lactone-degrading enzyme in aflatoxin B1-decontaminating Bacillus strains with potential use as feed additives. Food Chem. Toxicol. 2019, 124, 316-323. [CrossRef]

269. Ji, J.; Xie, W. Detoxification of Aflatoxin B1 by magnetic graphene composite adsorbents from contaminated oils. J. Hazard. Mater. 2020, 381, 120915. [CrossRef]

270. Grande-Tovar, C.D.; Chaves-Lopez, C.; Serio, A.; Rossi, C.; Paparella, A. Chitosan coatings enriched with essential oils: Effects on fungi involve in fruit decay and mechanisms of action. Trends Food Sci. Technol. 2018, 78, 61-71. [CrossRef] 
271. Zachetti, V.G.L.; Cendoya, E.; Nichea, M.J.; Chulze, S.N.; Ramirez, M.L. Preliminary study on the use of chitosan as an eco-friendly alternative to control Fusarium growth and mycotoxin production on maize and wheat. Pathogens 2019, 8, 8010029. [CrossRef] [PubMed]

272. Gunupuru, L.R.; Patel, J.S.; Sumarah, M.W.; Renaud, J.B.; Mantin, E.G.; Prithiviraj, B. A plant biostimulant made from the marine brown algae Ascophyllum nodosum and chitosan reduceFusarium head blight and mycotoxin contamination in wheat. PLoS ONE 2019, 14, e0220562. [CrossRef] [PubMed]

273. Piemontese, L.; Messia, M.C.; Marconi, E.; Falasca, L.; Zivoli, R.; Gambacorta, L.; Perrone, G.; Solfrizzo, M. Effect of gaseous ozone treatments on DON, microbial contaminants and technological parameters of wheat and semolina. Food Addit. Contam. Part A Chem. Anal. Control Expo. Risk Assess. 2018, 35, 760-771. [CrossRef] [PubMed]

274. Porto, Y.D.; Trombete, F.M.; Freitas-Silva, O.; de Castro, I.M.; Direito, G.M.; Ascheri, J.L.R. Gaseous Ozonation to Reduce Aflatoxins Levels and Microbial Contamination in Corn Grits. Microorganisms 2019, 7, 220. [CrossRef] [PubMed]

275. Alexandre, A.P.S.; Castanha, N.; Calori-Domingues, M.A.; Augusto, P.E.D. Ozonation of whole wheat flour and wet milling effluent: Degradation of deoxynivalenol (DON) and rheological properties. J. Environ. Sci. Heal Part B Pestic. Food Contam. Agric. Wastes 2017, 52, 516-524. [CrossRef]

276. Alexandre, A.P.S.; Castanha, N.; Costa, N.S.; Santos, A.S.; Badiale-Furlong, E.; Augusto, P.E.D.; Calori-Dominguesa, M.A. Ozone technology to reduce zearalenone contamination in whole maize flour: Degradation kinetics and impact on quality. J. Sci. Food Agric. 2019, 99, 6814-6821. [CrossRef]

277. Santos Alexandre, A.P.; Vela-Paredes, R.S.; Santos, A.S.; Costa, N.S.; Canniatti-Brazaca, S.G.; Calori-Domingues, M.A.; Augusto, P.E.D. Ozone treatment to reduce deoxynivalenol (DON) and zearalenone (ZEN) contamination in wheat bran and its impact on nutritional quality. Food Addit. Contam. Part A Chem. Anal. Control Expo. Risk Assess. 2018, 35, 1189-1199. [CrossRef]

278. Li, M.M.; Guan, E.Q.; Bian, K. Effect of ozone treatment on deoxynivalenol and quality evaluation of ozonised wheat. Food Addit. Contam. Part A Chem. Anal. Control Expo. Risk Assess. 2015, 32, 544-553. [CrossRef]

279. Agriopoulou, S.; Koliadima, A.; Karaiskakis, G.; Kapolos, J. Kinetic study of aflatoxins' degradation in the presence of ozone. Food Control 2016, 61, 221-226. [CrossRef]

280. Li, M.; Guan, E.; Bian, K. Structure Elucidation and Toxicity Analysis of the Degradation Products of Deoxynivalenol by Gaseous Ozone. Toxins 2019, 11, 474. [CrossRef] [PubMed]

281. Li, M.; Zhu, K.X.; Wang, B.W.; Guo, X.N.; Peng, W.; Zhou, H.M. Evaluation the quality characteristics of wheat flour and shelf-life of fresh noodles as affected by ozone treatment. Food Chem. 2012, 135, 2163-2169. [CrossRef] [PubMed]

282. Hassan, Y.I.; Zhou, T. Addressing the mycotoxin deoxynivalenol contamination with soil-derived bacterial and enzymatic transformations targeting the C3 carbon. World Mycotoxin J. 2018, 11, 101-111. [CrossRef]

283. Xia, X.; Zhang, Y.; Li, M.; Garba, B.; Zhang, Q.; Wang, Y.; Zhang, H.; Li, P. Isolation and characterization of a Bacillus subtilis strain with aflatoxin B1 biodegradation capability. Food Control 2017, 75, 92-98. [CrossRef]

284. Umesha, S.; Manukumar, H.M.G.; Chandrasekhar, B.; Shivakumara, P.; Kumar, J.S.; Raghava, S.; Avinash, P.; Shirin, M.; Bharathi, T.R.; Rajini, S.B.; et al. Aflatoxins and food pathogens: Impact of biologically active aflatoxins and their control strategies. J. Sci. Food Agric. 2017, 97, 1698-1707. [CrossRef] [PubMed]

285. Adebo, O.A.; Kayitesi, E.; Njobeh, P.B. Reduction of Mycotoxins during fermentation of Whole Grain Sorghum to Whole Grain ting (A Southern African Food). Toxins 2019, 11, 11030180. [CrossRef]

286. Tilocca, B.; Balmas, V.; Hassan, Z.U.; Jaoua, S.; Migheli, Q. A proteomic investigation of Aspergillus carbonarius exposed to yeast volatilome or to its major component 2-phenylethanol reveals major shifts in fungal metabolism. Int. J. Food Microbiol. 2019, 306, 108265. [CrossRef]

287. Farbo, M.G.; Urgeghe, P.P.; Fiori, S.; Marcello, A.; Oggiano, S.; Balmas, V.; Hassan, Z.U.; Jaoua, S.; Migheli, Q. Effect of yeast volatile organic compounds on ochratoxin A-producing Aspergillus carbonarius and A. ochraceus. Int. J. Food Microbiol. 2018, 284, 1-10. [CrossRef]

288. Liu, Y.; Chang, J.; Wang, P.; Yin, Q.; Huang, W.; Liu, C.; Bai, X.; Zhu, Q.; Gao, T.; Zhou, P. Effects of Saccharomyces cerevisiae on alleviating cytotoxicity of porcine jejunal epithelia cells induced by deoxynivalenol. $A M B$ Express 2019, 9, 137. [CrossRef] 
289. Mendieta, C.R.; Gomez, G.V.; Del Río, J.C.G.; Cuevas, A.C.; Arce, J.M.; Ávila, E.G. Effect of the addition of Saccharomyces Cerevisiae yeast cell walls to diets with mycotoxins on the performance and immune responses of broilers. J. Poult. Sci. 2018, 55, 38-46. [CrossRef]

290. Zhang, Z.; Li, M.; Wu, C.; Peng, B. Physical adsorption of patulin by Saccharomyces cerevisiae during fermentation. J. Food Sci. Technol. 2019, 56, 2326-2331. [CrossRef] [PubMed]

291. Jakopović, Ž.; Čiča, K.H.; Mrvčić, J.; Pucić, I.; Čanak, I.; Frece, J.; Pleadin, J.; Stanzer, D.; Zjalić, S.; Markov, K. Properties and fermentation activity of industrial yeasts Saccharomyces cerevisiae, S. uvarum, Candida utilis and Kluyveromyces marxianus exposed to AFB1, OTA and ZEA. Food Technol. Biotechnol. 2018, 56, $208-217$. [CrossRef] [PubMed]

292. Li, X.; Tang, H.; Yang, C.; Meng, X.; Liu, B. Detoxification of mycotoxin patulin by the yeast Rhodotorula mucilaginosa. Food Control 2019, 96, 47-52. [CrossRef]

293. Burgess, K.M.N.; Renaud, J.B.; McDowell, T.; Sumarah, M.W. Mechanistic insight into the biosynthesis and detoxification of fumonisin mycotoxins. ACS Chem. Biol. 2016, 11. [CrossRef] [PubMed]

294. Cence, K.; dos Santos, P.; Garcia, M.V.; Copetti, M.V.; Valduga, E.; Cansian, R.L.; Zeni, J.; Backes, G.T. Enzymatic biocontrol of spoilage fungi from salami. LWT 2019, 115, 108457. [CrossRef]

295. Tarazona, A.; Gómez, J.V.; Mateo, E.M.; Jiménez, M.; Mateo, F. Antifungal effect of engineered silver nanoparticles on phytopathogenic and toxigenic Fusarium spp. and their impact on mycotoxin accumulation. Int. J. Food Microbiol. 2019, 306, 108259. [CrossRef]

296. Zhou, Y.; Wu, S.; Wang, F.; Li, Q.; He, C.; Duan, N.; Wang, Z. Assessing the toxicity in vitro of degradation products from deoxynivalenol photocatalytic degradation by using upconversion nanoparticles@ $\mathrm{TiO}_{2}$ composite. Chemosphere 2020, 238, 124648. [CrossRef]

297. González-Jartín, J.M.; de Castro Alves, L.; Alfonso, A.; Piñeirob, Y.; Vilar, S.Y.; Gomez, M.G.; Osorio, Z.V.; Sainz, M.J.; Vieytes, M.R.; Rivas, J.; et al. Detoxification agents based on magnetic nanostructured particles as a novel strategy for mycotoxin mitigation in food. Food Chem. 2019, 294, 60-66. [CrossRef]

298. Chaudhari, A.K.; Dwivedy, A.K.; Singh, V.K.; Das, S.; Singh, A.; Dubey, N.K. Essential oils and their bioactive compounds as green preservatives against fungal and mycotoxin contamination of food commodities with special reference to their nanoencapsulation. Environ. Sci. Pollut. Res. 2019, 26, 25414-25431. [CrossRef]

299. Perczak, A.; Juś, K.; Gwiazdowska, D.; Marchwińska, K.; Waśkiewicz, A. The Efficiency of Deoxynivalenol Degradation by Essential Oils under In Vitro Conditions. Foods 2019, 8, 403. [CrossRef]

300. Sanzani, S.M.; Reverberi, M.; Geisen, R. Mycotoxins in harvested fruits and vegetables: Insights in producing fungi, biological role, conducive conditions, and tools to manage postharvest contamination. Postharvest Biol. Technol. 2016, 122, 95-105. [CrossRef]

301. Aiko, V.; Mehta, A. Occurrence, detection and detoxification of mycotoxins. J. Biosci. 2015, 40, $943-954$. [CrossRef] [PubMed]

302. Sánchez-Montero, L.; Córdoba, J.J.; Alía, A.; Peromingo, B.; Núñez, F. Effect of Spanish smoked paprika "Pimentón de La Vera" on control of ochratoxin A and aflatoxins production on a dry-cured meat model system. Int. J. Food Microbiol. 2019, 308, 108303. [CrossRef] [PubMed]

303. Kollia, E.; Proestos, C.; Zoumpoulakis, P.; Markaki, P. Capsaicin, an inhibitor of Ochratoxin A production by Aspergillus section Nigri strains in grapes (Vitis vinifera L.). Food Addit. Contam. Part. A 2019, 36, 1-13. [CrossRef] [PubMed]

(C) 2020 by the authors. Licensee MDPI, Basel, Switzerland. This article is an open access article distributed under the terms and conditions of the Creative Commons Attribution (CC BY) license (http://creativecommons.org/licenses/by/4.0/). 